\title{
A new cryptic species of the Pristimantis lacrimosus group (Anura, Strabomantidae) from the eastern slopes of the Ecuadorian Andes
}

\author{
Julio C. Carrión-Olmedo ${ }^{1}$, Santiago R. Ron ${ }^{1}$ \\ 1 Museo de Zoología, Escuela de Ciencias Biológicas, Pontificia Universidad Católica del Ecuador, Av. 12 de Octubre y Roca, Aptdo. 17-01-2184, \\ Quito, Ecuador \\ http://zoobank.org/62F72992-7781-495B-8899-E72AE637ABD0 \\ Corresponding author: Santiago R. Ron (santiago.r.ron@gmail.com)
}

Academic editor: Alexander Haas • Received 11 January 2021 • Accepted 6 May 2021 • Published 23 July 2021

\begin{abstract}
With 566 species, the neotropical genus Pristimantis is the most speciose vertebrate genus. As a result of its striking diversity, taxonomic reviews remain a challenge. Herein, we present an updated phylogeny of the Pristimantis lacrimosus group and describe a new species from Llanganates and Sangay National Parks. We also report, for the first time, the phylogenetic position of Pristimantis degener, P. eugeniae, P. katoptroides, and P. petersi. Based on our phylogeny, we add two species to the Pristimantis lacrimosus group. Through the integration of molecular and bioacoustic evidence, we describe a new species which was hidden under "Pristimantis petersi". Pristimantis petersioides sp. nov. is most closely related to Pristimantis petersi and an undescribed species from Peru. It can be distinguished from $P$. petersi by its advertisement call and large genetic differences (uncorrected $p$-genetic distances $7.9 \%$ to $8.4 \%$ for gene $16 \mathrm{~S}$ ). Moreover, the new species and P. petersi are not sister species. We suggest assigning the new species to the Endangered Red List category because it has a small distribution range with deforestation as result of agriculture and other anthropogenic influences.
\end{abstract}

\section{Key Words}

Amphibia, Bioacoustics, Conservation, Diversity, National Parks, Phylogeny, Taxonomy

\section{Introduction}

The genus Pristimantis Jiménez de la Espada, 1870 has bewildered scientists for its striking diversity. Comprising 566 Neotropical species it is the most speciose vertebrate genus (Hedges et al. 2008; Frost 2021). In Ecuador, this genus encompasses more than one third of all anuran species, with 233 out of 640 species (Ron et al. 2019).

The astounding species richness of Pristimantis has been attributed to terrestrial breeding - direct embryonic development without a tadpole stage (Padial et al. 2014) - and the appearance of geographic barriers as result of the Andean uplift (Lynch and Duellman 1997; Mendoza et al. 2015). However, other sympatric Andean genera with similar reproductive mode (e.g., Strabomantis
Peters, 1863) and age are not as diverse suggesting that terrestrial breeding and Andean uplift are not the only factors explaining the high diversity of Pristimantis.

The number of described species of Pristimantis is increasing rapidly as result of the use of DNA sequences allowing the discovery of a large number of cryptic species. DNA sequences helps to achieve better informed taxonomic decisions and speed up species discovery with more than 40 species of Pristimantis (e.g. Ortega et al. 2015; Guayasamin et al. 2017; Páez and Ron 2019) described in Ecuador in the last five years. In some clades, the number of undescribed species outnumbers described species (e.g., Ortega et al. 2015; Páez and Ron 2019) suggesting that there could be hundreds of undescribed species of Pristimantis. 
Taxonomy within this group have been problematic and unstable because most species descriptions have been based on morphological traits (Lynch and Duellman 1997), which can be highly variable and homoplastic (e.g. Guayasamin et al. 2015; Páez and Ron 2019). Taxonomic problems in Pristimantis are still pervasive and are still far from being fully resolved (e.g., Páez and Ron 2019; Reyes-Puig et al. 2019; Moravec et al. 2020).

One clade of Pristimantis containing undescribed species is the Pristimantis lacrimosus species group (Ron et al. 2020). Hedges et al. (2008) proposed it as monophyletic based on molecular data from only three species. However, more recent phylogenies with better species sampling showed that this group was paraphyletic (Padial et al. 2014; Rivera-Correa and Daza 2016). Rivera-Correa and Daza (2016) identified two non-sister clades within the Pristimantis lacrimosus species group, "clade A" endemic to Colombia and "clade B" composed by species from Central America, Ecuador, and Peru. González-Durán et al. (2017) proposed the Pristimantis boulengeri group for "clade A" and hypothesized that "clade B" corresponds to the P. lacrimosus species group. That assignment was questioned by Rivera-Correa and Daza (2020) but was demonstrated as correct by Ron et al. (2020) who included in their phylogeny, for the first time, the type species for the group, P. lacrimosus (Jiménez de la Espada, 1875). Ron et al. (2020) also described three new species and redefined the group to include all descendant species of the most recent common ancestor of $P$. eremitus (Lynch, 1980 ) and $P$. lacrimosus for a total of 36 formally described species.

Despite these advances, there still are species of the Pristimantis lacrimosus group which have never been included in molecular phylogenies. One of them is Pristimantis petersi (Lynch \& Duellman, 1980). Since its description, this species suffered several taxonomic changes. Lynch (1991) changed its name to Eleutherodactylus petersorum to avoid homonymy with a Mexican species with the same epithet, which now is known as Eleutherodactylus nitidus (Peters 1870). Additionally, Lynch (1996) created the name Eleutherodactylus johnwrighti, as an amend to the previous epithet petersorum. Afterwards, Frost (2009) applied Article 59.4 of the International Code of Zoological Nomenclature making Eleutherodactylus johnwrighti and Eleutherodactylus petersorum invalid replacement names because the taxa in question are not congeneric and recovered the first epithet used for this species.

Pristimantis petersi has been usually assigned to the P. lacrimosus species group. Lynch and Duellman (1980) placed it in the P. unistrigatus group, P. lacrimosus assembly. Later, Lynch and Duellman (1997) placed it in the unistrigatus group, martinicensis series. Hedges et al. (2008) proposed this species as a member of the Pristimantis lacrimosus group and Padial et al. (2014) and Rivera-Correa and Daza (2016) followed this proposal but without including Pristimantis petersi in their phylogenies.
Pristimantis petersi holotype (KU 143508) is from $16.5 \mathrm{~km}$ NNE of Santa Rosa, Napo Province, $1700 \mathrm{~m}$. However, most specimens used in the species description by Lynch and Duellman (1980) were from other populations including localities in the central Andes of Colombia (Huila and Putumayo Departments), and central Ecuador (Napo and Pastaza provinces). As currently defined, Pristimantis petersi is considered to have a wide distribution from the central Andes of Colombia (Lynch and Duellman 1980; Mueses-Cisneros 2005; Stuart et al. 2008) to the eastern slopes of the Ecuadorian Andes, from Sucumbíos to Morona Santiago Provinces at altitudes ranging between 1400-2000 m a.s.l (Brito et al. 2017; Ron et al. 2019). Lynch and Duellman (1980) mentioned that Pristimantis petersi exhibits body size variation throughout its distribution range and, remarkably, realized that individuals from the upper Pastaza trench were larger than individuals from the type locality, Ecuador, and suspected that populations from Pastaza may represent another species.

The wide geographic distribution of Pristimantis petersi suggest that it may be a species complex. Recent reviews of Andean Pristimantis suggest that most species have highly restricted distributions. For example, in the subgenus Huicundomantis Páez \& Ron, 2019 all species had distribution ranges below $5000 \mathrm{~km}^{2}$ and the seemingly large distribution of " $P$. phoxocephalus" and " $P$. riveti" were an artifact of the combined distribution of several cryptic species (Páez and Ron 2019). Similarly, "P. calcarulatus" was considered to be distributed in the Andes from central Ecuador to southern Colombia (Hutter and Guayasamin 2015). However, genetic and morphological evidence demonstrated that " $P$. calcarulatus" was a complex of three different species, each with a small distribution range. Similar results have been found within "P. orestes", "P. ornatissimus" (Guayasamin et al. 2017; Urgiles et al. 2019), and $P$. ventrimarmoratus (Moravec et al. 2020). It is unclear if species of Andean Pristimantis with large distributions $\left(>10000 \mathrm{~km}^{2}\right)$ actually exist. We are unaware of any species of Pristimantis with such distribution withstanding a taxonomic review based on genetic and phenotypic characters. The available evidence suggests that species with seemingly large distributions, like $P$. petersi, may represent species complexes.

The existence of cryptic diversity within P. petersi is also suggested by reports of body size differences among populations of $P$. petersi (Lynch and Duellman 1980; Brito et al. 2017). Recent fieldwork conducted by field staff of the QCAZmuseum from Pontificia Universidad Católica del Ecuador resulted in collections of P. petersi near its type locality and in the discovery of populations of a species similar to $P$. petersi in Sangay National Park and Llanganates National Park. Through the integration of genetic and bioacoustic data with an exhaustive population sampling, we demonstrate that those populations are distinct from $P$. petersi. We describe the new species and review the content and phylogenetic relationships of the Pristimantis lacrimosus group. 


\section{Materials and methods}

\section{Nomenclature}

Taxon names follow Duellman and Lehr (2009) and AmphibiaWeb (2019).

\section{DNA extraction, amplification and sequencing}

We inferred the phylogenetic relationships of the new species and closely related taxa based on DNA sequences of one nuclear gene: Recombination activating gene 1 (RAG-1) and three mitochondrial genes: 12S rRNA (12S), 16S rRNA (16S), NADH dehydrogenase subunit 1 (ND1) and their flanking tRNAs. DNA was extracted from muscle or liver tissue preserved in $95 \%$ ethanol using standard Guanidine thiocyanate extraction protocols. We used polymerase chain reaction (PCR) to amplify DNA fragments. Primers used for amplification of $12 \mathrm{~S}$ were $\mathrm{t}$-Phe-frog and $\mathrm{t}$-Val-frog (Wiens et al. 2005), 12SZ-L and 12SK-H (Goebel et al. 1999), for 16S, primers were 12sL13 (Feller and Hedges 1998), 16L19 and 16H36E (Heinicke et al. 2007), for ND1, primers were WL379, WL384, t-Met-frog and 16S-frog (Moen and Wiens 2009), for RAG1, primers were R182, R270, Rag1FF2, Rag1FR2 (Heinicke et al. 2007). PCR amplification was performed under standard protocols and sequenced in both directions by the Macrogen Sequencing Team (Macrogen Inc., Seoul, Korea). All sequences were assembled in Geneious 7.1.7. and then exported to Mesquite version 3.40 where each genomic region was aligned separately using default parameters in Muscle (Edgar 2004). Unambiguous alignment errors were corrected manually in Mesquite (Maddison and Maddison 2018). The aligned matrix is available in https://doi.org/10.5281/ zenodo.3785738. To calculate the uncorrected pairwise genetic $p$-distances of $16 \mathrm{~S}$ we used MEGA7 on a fragment of $653 \mathrm{pb}$ (Kumar et al. 2016).

We included 156 GenBank sequences of congeneric species. To find relevant sequences in GenBank, we made a $16 \mathrm{~S}$ BLASTn search with the sequences of the new species (Table 1). These searches showed that the most similar sequences belong to species from the $P$. lacrimosus group: $P$. schultei (Duellman, 1990) (identity 88.62\%, accession EF493681), P. bromeliaceus (Lynch, 1979) (identity $86.92 \%$, accession EF493351.1) and others such as $P$. galdi Jiménez de la Espada, 1870 (identity 87.76\%, accession EU186670.1), and $P$. cf. mendax (Duellman, 1978) (identity 87.07\%, accession EU186659.1). Therefore, we included sequences used in previous studies on P. lacrimosus group (e.g. Arteaga et al. 2013; Padial et al. 2014; Ortega-Andrade et al. 2015; Rivera-Correa and Daza 2016; Chávez and Catenazzi 2016; Shepack et al. 2016; Guayasamin et al. 2017; Ron et al. 2020; Rivera-Correa and Daza 2020). Samples of Niceforonia nigrovittata (Andersson, 1945), N. elassodisca
(Lynch, 1973), and P. w-nigrum (Boettger, 1892) were set as outgroups. The combined DNA matrix had up to $4067 \mathrm{bp}$ and 140 terminals.

\section{Phylogeny}

The phylogeny was inferred using Maximum Likelihood as optimality criterion. To choose the substitution models that best adjusted to our sequences, we used Model Finder under the command MFP+MERGE (Kalyaanamoorthy et al. 2017; Chernomor et al. 2016) as implemented in IQTREE 1.6.8 (Nguyen et al. 2015). We partitioned the sequences by gene and by codon position in coding genes. For the ML search we used IQ-TREE 1.6.8 (Nguyen et al. 2015) under default values. To assess branch support we obtained ultrafast bootstrap values from 2000 pseudoreplicates and 10000 iterations as maximum number to stop (commands -bb 2000 and -nm 10000 in IQ-TREE) and SH-like approximate likelihood ratio test (SH-aLRT) with 1000 replicates (-alrt 1000 command, Guindon et al. 2010). We considered that branches with bootstrap values $>95$ and SH-aLRT values $>80$ had strong support. Additionally, we inferred phylogenies from mithocondrial DNA and the nuclear gene RAG1 separately to compare the topology of the phylogenetic tree derived from DNA regions with independent segregation.

\section{Morphology}

Diagnostic characters and comparisons are based on preserved specimens from Museo de Zoología at Pontificia Universidad Católica del Ecuador, Quito (QCAZ) and, when available digital photographs. Examined specimens are listed as Suppl. material 1. Character definitions and terminology follow Duellman and Lehr (2009). For subarticular tubercle terminology we follow Ron et al. (2020). Sex was determined by presence of nuptial pads or vocal slits, and direct inspection of gonads. Descriptions of coloration and variation in life are based on digital photographs. We examined the following qualitative characters: dorsal and ventral skin texture, presence of tympanic membrane and annulus, snout shape, presence of rostral papilla, presence of vomerine odontophores, presence of vocal slits and gular sac in males, relative length of fingers and toes, disc shape, presence of dorsolateral, discoidal and supratympanic folds, presence of lateral fringes on fingers and toes, presence of palmar, ulnar, tarsal, metatarsal, subarticular, supernumerary, knee, heel, and eyelid tubercles, and webbing on fingers and toes. We follow the name "hyperdistal tubercle" proposed in Ospina-Sarria and Duellman (2019) to refer to the most distal tubercle in Fingers and Toes.

Adults were measured with digital calipers (to the nearest $\pm 0.01 \mathrm{~mm}$ ) for eleven morphological variables, following Duellman and Lehr (2009): (1) snout-vent length; (2) tibia length; (3) foot length; (4) head length; 
Table 1. Genbank accession numbers for DNA sequences used for phylogenetic analyses.

\begin{tabular}{|c|c|c|c|c|c|}
\hline Species & Voucher & $12 S$ & $16 \mathrm{~S}$ & RAG1 & ND1 \\
\hline Niceforonia elassodisca & QCAZ52495 & MW567328 & MW567375 & MW451754 & MW567403 \\
\hline Niceforonia nigrovittata & QCAZ59410 & NA & MW567340 & NA & NA \\
\hline Pristimantis acerus & KU 217786 & EF493678.1 & EF493678.1 & NA & NA \\
\hline P. actites & KU 217830 & NA & EF493696.1 & EF493432.1 & NA \\
\hline \multirow[t]{4}{*}{ P. acuminatus } & CORBIDI 4769 & MN128391 & NA & NA & NA \\
\hline & QCAZ53263 & MN128394 & NA & NA & NA \\
\hline & CORBIDI 7469 & MN128392 & NA & NA & NA \\
\hline & CORBIDI 7579 & MN128393 & NA & NA & NA \\
\hline P. aff. subsigillatus & QCAZ58017 & MW567302 & MW567373 & MW451755 & MW567411 \\
\hline P. altamazonicus & KU 215460 & EF493670.1 & EF493670.1 & NA & NA \\
\hline P. amaguanae & QCAZ39274 & MT636506 & MT636529 & MT635622 & MT635661 \\
\hline P. andinognomus & QCAZ16683 & NA & MW567356 & MW451748 & MW567390 \\
\hline P. angustilineatus & UVC 15828 & NA & JN371034.1 & NA & NA \\
\hline P. appendiculatus & KU177637 & EF493524.1 & EF493524.1 & NA & NA \\
\hline P. aureolineatus & QCAZ42286 & MT636509 & MT636530 & MT635626 & NA \\
\hline P. bambu & QCAZ46708 & NA & MW567357 & MW451727 & NA \\
\hline P. boulengeri & MHUAA 8951 & NA & KU724435.1 & NA & NA \\
\hline P. brevifrons & nrps 0059 & JN991498.1 & JN991433.1 & NA & NA \\
\hline \multirow[t]{2}{*}{ P. bromeliaceus } & QCAZ16699 & MT636505 & MT636527 & MT635618 & MT635659 \\
\hline & QCAZ62940 & MT636512 & MT636523 & NA & MT635669 \\
\hline P. calcarulatus & KU 177658 & EF493523.1 & EF493523.1 & NA & NA \\
\hline P. cedros & MZUTI 1713 & NA & KT210155.1 & NA & NA \\
\hline P. celator & QCAZ66230 & MW567326 & MW567368 & MW451723 & MW567406 \\
\hline P. cf. mendax & MTD 45080 & EU186659.1 & EU186659.1 & NA & NA \\
\hline \multirow[t]{2}{*}{ P. conspicillatus } & QCAZ28448 & MW567327 & MW567377 & MW451749 & NA \\
\hline & QCAZ55439 & NA & MW567358 & MW451746 & MW567394 \\
\hline P. crucifer & KU 177733 & EU186736.1 & EU186718.1 & NA & NA \\
\hline P. curtipes & QCAZ40722 & MW567323 & MW567363 & MW451750 & MW567416 \\
\hline P. degener & QCAZ40304 & MW567305 & MW567376 & MW451761 & MW567379 \\
\hline \multirow[t]{2}{*}{ P. diadematus } & KU 221999 & EU186668.1 & EU186668.1 & NA & NA \\
\hline & QCAZ59442 & MW567325 & MW567354 & MW451735 & MW567419 \\
\hline P. dissimulatus & KU179090 & EF493522.1 & EF493522.1 & NA & NA \\
\hline P. dorsopictus & MHUAA7638 & KP082864.1 & KP082874.1 & NA & NA \\
\hline \multirow[t]{2}{*}{ P. ecuadorensis } & CJ 5350 & KX785339 & KX785343 & NA & KX785347 \\
\hline & CJ 5351 & KX785340 & KX785344 & NA & KX785348 \\
\hline P. enigmaticus & QCAZ40918 & MT636513 & MT636520 & MT635636 & MT635670 \\
\hline \multirow[t]{3}{*}{ P. eremitus } & QCAZ40002 & NA & NA & MW451729 & MW567391 \\
\hline & QCAZ49652 & NA & MW567366 & MW451732 & MW567409 \\
\hline & QCAZ43392 & NA & MW567333 & NA & NA \\
\hline \multirow[t]{2}{*}{ P. engeniae } & DHMECN8809 & MT853052 & MT853039 & NA & NA \\
\hline & QCAZ52367 & MW567322 & MW567353 & MW451743 & MW567380 \\
\hline \multirow[t]{4}{*}{ P. galdi } & QCAZ32368 & EU186670.1 & EU186670.1 & EU186746 & NA \\
\hline & QCAZ58885 & MW567304 & MW567355 & MW451756 & MW567410 \\
\hline & QCAZ58886 & NA & MW567334 & MW451757 & NA \\
\hline & QCAZ58888 & NA & MW567335 & MW451739 & NA \\
\hline P. glandulosus & KU 218002 & EF493676.1 & EF493676.1 & NA & NA \\
\hline P. imitatrix & KU 215476 & EF493824.1 & EF493667.1 & NA & NA \\
\hline P. inusitatus & KU 218015 & EF493677.1 & NA & NA & NA \\
\hline P. jaguensis & MHUAA 7249 & KP082862.1 & KP082870.1 & NA & NA \\
\hline \multirow[t]{2}{*}{ P. katoptroides } & QCAZ46360 & NA & MW567378 & MW451753 & MW567408 \\
\hline & QCAZ58897 & NA & MW567330 & NA & NA \\
\hline \multirow[t]{4}{*}{ P. lacrimosus } & QCAZ55238 & NA & MT636518 & MT635629 & MT635667 \\
\hline & QCAZ59474 & NA & MT636517 & MT635633 & NA \\
\hline & QCAZ40261 & NA & MT636524 & MT635623 & MT635671 \\
\hline & QCAZ59469 & NA & MT636516 & MT635632 & NA \\
\hline \multirow[t]{5}{*}{ P. limoncochensis } & QCAZ43794 & NA & MT636525 & MT635627 & MT635665 \\
\hline & QCAZ52987 & MN128397 & NA & NA & NA \\
\hline & QCAZ56316 & MN128398 & NA & NA & NA \\
\hline & QCAZ37277 & MN128396 & NA & NA & NA \\
\hline & QCAZ19180 & MN128395 & MT636532 & MT635620 & NA \\
\hline P. lymani & QCAZ46311 & NA & MW567365 & MW451752 & NA \\
\hline P. melanogaster & NA & EF493826.1 & EF493664.1 & NA & NA \\
\hline P. mindo & MZUTI 1382 & NA & KF801584.1 & NA & NA \\
\hline & MZUTI 1381 & NA & KF801583.1 & NA & NA \\
\hline & QCAZ56512 & NA & MT636522 & MT635630 & MT635668 \\
\hline & MZUTI 1756 & NA & KF801581.1 & NA & NA \\
\hline & QCAZ42197 & MT636508 & MT636531 & MT635625 & MT635664 \\
\hline P. moro & AJC 1860 & JN991520.1 & JN991454.1 & JQ025191.1 & NA \\
\hline & AJC 1753 & JN991519.1 & JN991453.1 & JQ025192.1 & NA \\
\hline P. muranunka & QCAZ54593 & NA & MW567358 & MW451762 & MW567393 \\
\hline
\end{tabular}




\begin{tabular}{|c|c|c|c|c|c|}
\hline Species & Voucher & $12 \mathrm{~S}$ & $16 \mathrm{~S}$ & RAG1 & ND1 \\
\hline P. nankints & QCAZ69137 & NA & MT636514 & MT635635 & NA \\
\hline \multirow[t]{4}{*}{ P. nyctophylax } & KU 177812 & EF493526.1 & EF493526.1 & NA & NA \\
\hline & QCAZ32288 & NA & MT636519 & MT635621 & MT635660 \\
\hline & KU 218147 & EF493525.1 & EF493525.1 & NA & NA \\
\hline & QCAZ49637 & NA & MT636521 & MT635628 & MT635666 \\
\hline P. olivaceus & CORBIDI 17473 & NA & KX155579 & NA & NA \\
\hline \multirow[t]{4}{*}{ P. omeviridis } & QCAZ55392 & MN128401 & NA & NA & NA \\
\hline & FHGO 7192 & MN128399 & NA & NA & NA \\
\hline & QCAZ10564 & MN128400 & MK881398 & MK881312 & MT635658 \\
\hline & QCAZ19664 & NA & EU13057 & MT635619 & NA \\
\hline P. orcesi & KU 218021 & EF493679.1 & EF493679.1 & NA & NA \\
\hline \multirow[t]{3}{*}{ P. ornatissimus } & MZUTI 4798 & KU720464 & KU720463 & NA & KU720480 \\
\hline & MZUTI 4806 & KX785337 & KX785341 & NA & KX785345 \\
\hline & MZUTI 4807 & KX785338 & KX785342 & NA & KX785346 \\
\hline P. pahuma & MZUTI 493 & NA & KT210158.1 & NA & NA \\
\hline \multirow[t]{4}{*}{ P. petersi } & QCAZ63455 & MW567303 & MW567369 & MW451725 & MW567405 \\
\hline & QCAZ51390 & NA & MZ219640 & MZ219636 & MZ219631 \\
\hline & QCAZ15988 & NA & MZ219641 & MZ219635 & MZ219633 \\
\hline & QCAZ63456 & NA & MW567367 & MW451726 & MW567404 \\
\hline \multirow[t]{17}{*}{ P. petersioides sp. nov. } & QCAZ58936 & NA & MW567331 & MW451740 & MW567401 \\
\hline & QCAZ58937 & MW567306 & MW567336 & MW451758 & MW567381 \\
\hline & QCAZ58951 & MW567321 & MW567339 & MW451741 & MW567389 \\
\hline & QCAZ58939 & MW567307 & MW567337 & MW451759 & MW567386 \\
\hline & QCAZ59167 & MW567309 & MW567332 & MW451763 & MW567387 \\
\hline & QCAZ58944 & MW567308 & MW567338 & MW451760 & MW567395 \\
\hline & QCAZ59456 & MW567312 & MW567352 & MW451744 & MW567388 \\
\hline & QCAZ59466 & MW567314 & MW567343 & MW451745 & MW567383 \\
\hline & QCAZ59472 & MW567317 & MW567347 & MW451719 & MW567382 \\
\hline & QCAZ59479 & MW567318 & MW567348 & MW451724 & MW567384 \\
\hline & QCAZ59625 & MW567319 & MW567349 & MW451720 & MW567385 \\
\hline & QCAZ59470 & MW567316 & MW567345 & MW451737 & MW567397 \\
\hline & QCAZ59471 & MW567311 & MW567346 & MW451738 & MW567420 \\
\hline & QCAZ59468 & MW567315 & MW567344 & MW451742 & MW567402 \\
\hline & QCAZ59458 & MW567310 & MW567341 & MW451736 & MW567395 \\
\hline & QCAZ59461 & MW567313 & MW567342 & MW451718 & MW567398 \\
\hline & QCAZ49027 & NA & MZ219642 & MZ219638 & MZ219634 \\
\hline P. platydactylus & MNCNDNA 5524 & FJ438811.1 & EU192255.1 & NA & NA \\
\hline \multirow[t]{2}{*}{ P. pluvialis } & CORBIDI 11862 & NA & KX155577 & NA & NA \\
\hline & CORBIDI 16695 & NA & KX155578 & NA & NA \\
\hline \multirow[t]{2}{*}{ P. pulchridormientes } & CORBIDI 15563 & NA & KX664106 & NA & NA \\
\hline & CORBIDI 15566 & NA & KX664107 & NA & NA \\
\hline P. pulvinatus & KU 181015 & EF186741.1 & EF186723.1 & NA & NA \\
\hline P. pycnodermis & KU 218028 & EF493680.1 & EF493680.1 & NA & NA \\
\hline P. quaquaversus & QCAZ25613 & MW567329 & MW567360 & MW451722 & MW567407 \\
\hline P. romeroae & QCAZ41121 & MT636507 & MT636528 & MT635624 & MT635662 \\
\hline \multirow[t]{2}{*}{ P. rubicundus } & QCAZ58932 & NA & MT372670 & MT372613 & NA \\
\hline & KU 212220 & EF493681.1 & EF493681.1 & NA & NA \\
\hline P. schultei & KU 291702 & EF493351.1 & EF493351.1 & NA & NA \\
\hline \multirow[t]{7}{*}{ Pristimantis sp. } & QCAZ63481 & NA & MW567350 & NA & MW567399 \\
\hline & QCAZ63482 & NA & MW567351 & MW451721 & MW567400 \\
\hline & ROM 43978 & EU186678.1 & EU186678.1 & NA & NA \\
\hline & QCAZ60398 & NA & MT636515 & MT635634 & NA \\
\hline & QCAZ58956 & MT636511 & MT636526 & MT635631 & NA \\
\hline & CORBIDI 13805 & NA & MZ219639 & MZ219637 & MZ219632 \\
\hline & MECN 10117 & $\mathrm{NA}$ & KF801580.1 & NA & NA \\
\hline \multirow[t]{5}{*}{ P. subsigillatus } & QCAZ45268 & NA & MW567370 & MW451730 & MW567412 \\
\hline & QCAZ49370 & MW567320 & MW567371 & MW451731 & MW567413 \\
\hline & QCAZ51314 & NA & MW567361 & MW451734 & MW567392 \\
\hline & QCAZ50012 & NA & MW567372 & MW451733 & MW567414 \\
\hline & MHNC 12845 & MN128403 & NA & NA & NA \\
\hline P. tantanti & CORBIDI 12987 & MN128402 & NA & NA & NA \\
\hline P. truebae & QCAZ13752 & NA & MW567362 & MW451747 & MW567417 \\
\hline & QCAZ42714 & MW567324 & MW567364 & MW451751 & MW567418 \\
\hline P. urani & MHUAA 7471 & NA & KU724442.1 & NA & NA \\
\hline P. w-nigrum & QCAZ45200 & MT636510 & MT372703 & МТ372600 & MT372569 \\
\hline & QCAZ46256 & NA & MT372704 & MT372603 & MT372571 \\
\hline & QCAZ41818 & NA & MT372691 & NA & MT635663 \\
\hline & QCAZ52365 & NA & MW567374 & MW451728 & MW567415 \\
\hline P. zorro & MHUAA 8813 & NA & MT747833 & NA & NA \\
\hline & MHUAA 8814 & NA & MT747834 & NA & NA \\
\hline & MHUAA 8816 & NA & MT747835 & NA & NA \\
\hline
\end{tabular}


(5) head width; (6) eye diameter; (7) tympanum diameter; (8) interorbital distance; (9) eye width; (10) internarial distance; and (11) eye-nostril distance. Morphometric analyses were performed based on measurements of adults (number of specimens in parenthesis): P. petersi (12), P. aff. petersi (new species; 54).

To explore morphometric differentiation between species, we applied a Principal Components Analysis (PCA). To remove the effect of size covariation, we carried out linear regressions between the morphometric variables and SVL. The PCA was applied to the residuals of the regressions. Morphometric variables associated with eyes (i.e., eye diameter, interorbital distance, eyelid width, internarial distance and eye-nostril distance) had weak correlation with snout-vent length. Low correlation appears to be a result of the difficulty of defining the eye edge on preserved specimens. Therefore, were removed those variables from the analysis. Prior to the PCA, we ran a MANOVA on the residuals to test for morphometric sexual dimorphism independent of size differences . Because the MANOVA was non-significant, we pooled the measurements of both sexes on a single PCA.

\section{Bioacoustics}

To assess species limits between the new species and the closely related $P$. petersi, we analyzed calls from three males of the new species: QCAZ58940, SVL $=19.3 \mathrm{~mm}$, from Refuge 1, Sardinayacu, Sangay National Park, Morona Santiago Province $\left(2.0983^{\circ} \mathrm{S}, 78.1555^{\circ} \mathrm{W}, 1406 \mathrm{~m}\right)$ collected on 21 January 2015, air temperature $19^{\circ} \mathrm{C}$, recorded in situ by Daniel Rivadeneira, and QCAZ59466, $\mathrm{SVL}=19.1 \mathrm{~mm}$, from the ravines of Yurugyacu river, Zarentza community, Llanganates National Park, Pastaza Province, $\left(1.3524^{\circ} \mathrm{S}, 78.0597^{\circ} \mathrm{W}, 1419 \mathrm{~m}\right)$ collected on February 242015 and recorded in captivity on 6 March 2015 by Santiago R. Ron and one male not collected from Sardinayacu, Sangay National Park, Morona Santiago Province, recorded by Diego Batallas. Advertisement calls of $P$. petersi were analyzed from two adult males (not collected) from near its type locality, Cocodrilos, Napo Province, $\left(0.66812^{\circ} \mathrm{S}, 77.7975^{\circ} \mathrm{W}, 1725 \mathrm{~m}\right)$ recorded on 22 June 2016 by Santiago R. Ron. We did not have size data for the recorded individuals of $P$. petersi. However, we collected other adult males on the same night and chorus and used the size of those individuals to assess interpopulation size differences. For two of the recorded males of the new species, SVL was 19.1 and $19.3 \mathrm{~mm}$; for Pristimantis petersi average SVL was $17.2 \mathrm{~mm}$ (16.5$17.8 \mathrm{~mm} ; n=3$ ). Recordings were made in WAV format, with a sample rate of $44100 \mathrm{~Hz}$ and 16-bits. Call variables were measured with RAVEN PRO 1.5 (Charif et al. 2010), under a Hanning function, 2048 DFT, sample rate of $46 \mathrm{kHz}$ and a grid spacing of $20 \mathrm{kHz}$.

Most of our recordings lacked temperature information. However, the variables that allowed us to differentiate the new species from the closely related P. petersi, where call duration and call frequency which are static and are not strongly influenced by ambient temperature (Köhler et al. 2017). Moreover, equatorial Andean forests have low seasonality and with low temperature variation, so it is unlikely that our results are biased by temperature differences between localities or seasons. At Zarentza, for example, in 2015, the monthly average of the minimum daily temperature varied between 14.7 (January) and $15.9{ }^{\circ} \mathrm{C}$ (May) while at Cocodrilos (where recordings for $P$. petersi were made) it had a range between 15.1 (January) and $16.0{ }^{\circ} \mathrm{C}$ (November). Temperature data were obtained from the WorldClim database (https:// www.worldclim.org/).

For call measurements and terminology, we followed the call-centered approach by Köhler et al. (2017). We followed the step-by-step guide of Köhler et al. (2017) for measuring variables: we measured temporal variables such as call duration, call rate, call interval, call rise time and amplitude modulation in the oscillogram and the spectral variables such as frequency band, fundamental frequency, and dominant frequency in the spectrogram. Due to call structure, parameters such as notes, notes rates, note series, pulses and pulse rates were absent and only eight acoustic parameters (modified from Köhler et al. 2017) were measured: (1) Call duration $=$ time from beginning to end of the call, measured from oscillogram; (2) Call rate $=$ number of calls per minute; (3) Call interval = time from end of call to beginning of next call;(4) Call rise time $=$ time from beginning of call to point of maximum amplitude; (5) Amplitude modulation = change in the amplitude level of a sound wave over time; (6) Frequency band = difference between upper and lower frequencies measured visually along the entire call (7) Fundamental frequency $=$ frequency with highest energy on $1^{\text {st }}$ harmonic in the call; (8) Dominant frequency = frequency with highest energy along entire call. Recordings are deposited in the Sound Archive of Museo de Zoología QCAZof Pontificia Universidad Católica del Ecuador and are available at the Anfibios del Ecuador website, https:// bioweb.bio/faunaweb/amphibiaweb/).

\section{Results}

\section{Phylogeny and genetic distances}

The Maximum Likelihood tree (Fig. 1) is similar in topology to Rivera-Correa and Daza (2016), Rivera-Correa and Daza (2020), and Ron et al. (2020). Support values for the Pristimantis lacrimosus group is strong (bootstrap $=100$ ); this clade includes the species reported in Ron et al. (2020) as well as species not included in previous phylogenies as P. degener (Lynch and Duellman, 1997), $P$. petersi, and the new species. Additionally, we report for the first time the phylogenetic position of Pristimantis eugeniae (Lynch and Duellman, 1997) and P. katoptroides (Flores, 1988). Pristimantis engeniae is the sister species of a clade formed by P. glandulosus (Boulenger, 
1880), P. acerus (Lynch and Duellman, 1980), and P. inusitatus (Lynch and Duellman, 1980) (bootstrap = 99). Pristimantis katoptroides is sister to P. quaquaversus (Lynch, 1974) + P. melanogaster (Duellman and Pramuk, 1999). Pristimantis subsigillatus (Boulenger, 1902) was polyphyletic because two samples (KU 218147 and QCAZ49637) were more closely related to P. nyctophylax (Lynch, 1976) than to the other samples of P. subsigillatus. After reviewing the morphology of QCAZ49637 we concluded that it belongs to P. nyctophylax. Because KU 218147 is genetically identical, we also assigned it to P. nyctophylax.

The ML tree from mitochondrial DNA shows similar topology to the ML tree from all genes. The best-fit models of DNA evolution for each partition are available as Suppl. material 2.
The mtDNA tree shows strong support for the Pristimantis lacrimosus group (bootstrap $=99$ ), for Pristimantis petersi $($ bootstrap $=100)$ and for the new species (bootstrap =99). The ML tree inferred from RAG1 shows lower support values but is congruent in showing a monophyletic Pristimantis lacrimosus group (bootstrap = 91) and in confirming a close relationship between $P$. petersi and the new species. The mtDNA and RAG1 phylogenies do not show strongly supported incongruences. Mitochondrial DNA and RAG1 phylogenetic trees are available as Suppl. material 3.

The new species is the sister to $P$. petersi and an undescribed species from Cordillera Escalera, Peru. The uncorrected pairwise $p$-genetic distances for $16 \mathrm{~S}$ between P. petersi and the new species range from $7.9 \%$ to $8.4 \%$. The clade comprising these three species is sister to an

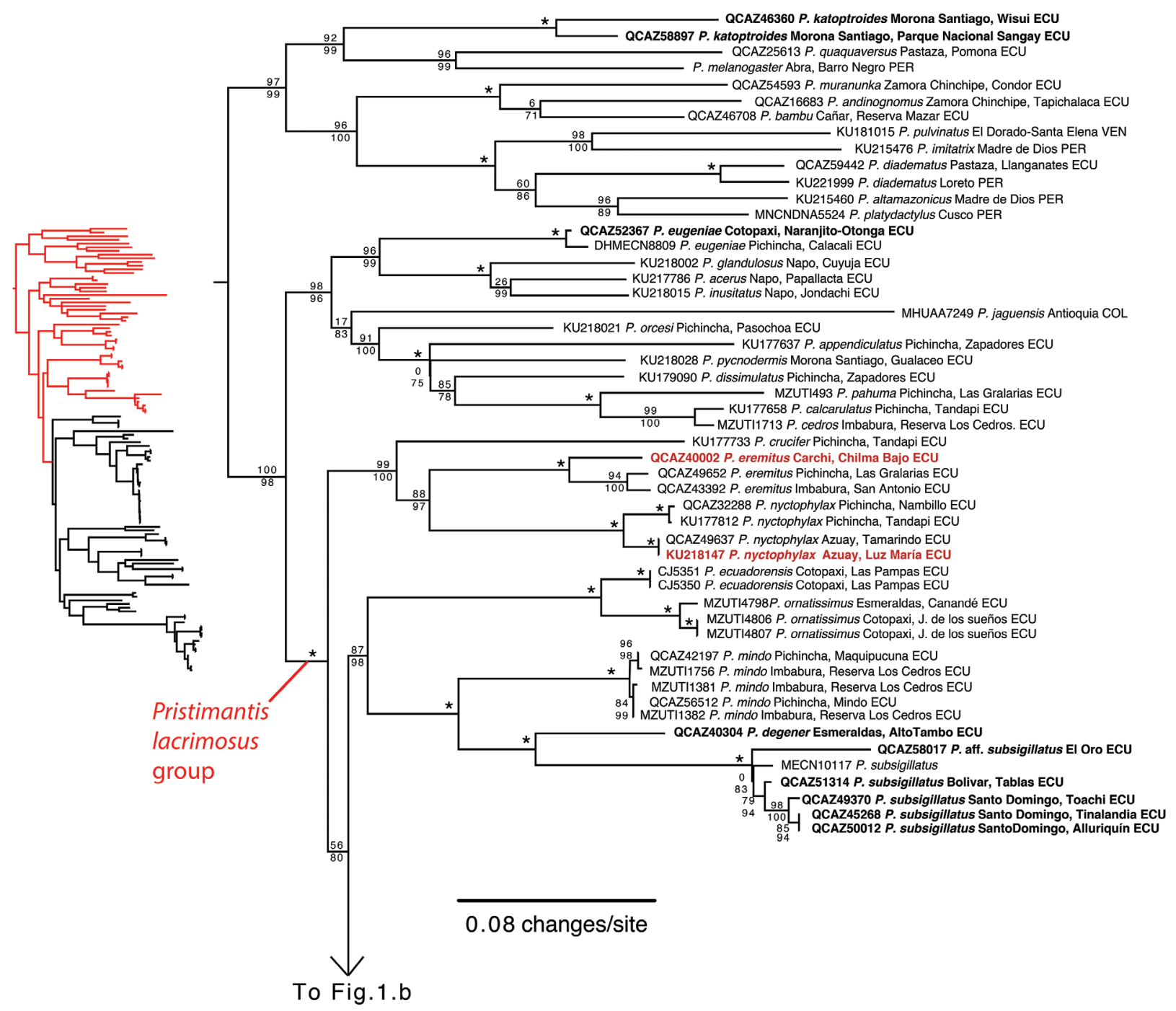

Figure 1. Maximum likelihood tree of the Pristimantis lacrimosus group inferred from a partitioned analysis of 4026 aligned sites of DNA sequences of the mitochondrial genes 12S, 16S, and ND-1 and the nuclear gene RAG-1. Bold characters highlight individuals included for the first time in a phylogeny, red taxa highlight previously misidentified species. Pristimantis petersioides sp. nov. is highlighted in blue. SH-aLRT support (above branch) and ultrafast bootstrap support (below) are shown as percentages; asterisks denote $100 \%$ for both measures. Outgroups are not shown. Number for voucher museum specimens are shown to the left of the species name; locality is shown to the right and country abbreviation at the end, as follows: ECU Ecuador, PER Peru, COL Colombia, VEN Venezuela, GUY Guyana, PAN Panama. 


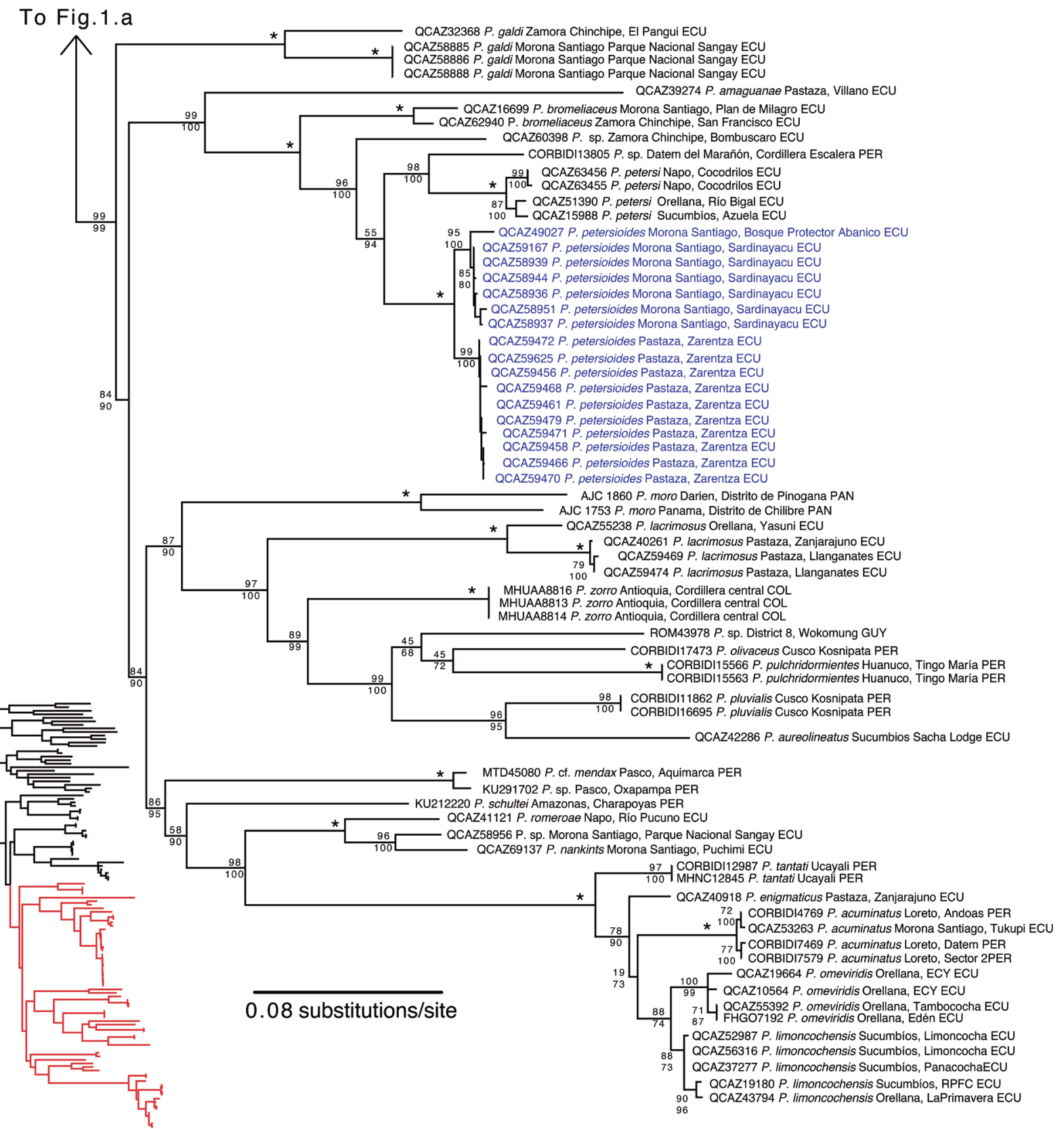

Figure 1. Continued.

undescribed species from Bombuscaro, Podocarpus National Park, Zamora Province, Ecuador. Samples of the new species separate in two sister clades, a northern clade in Zarentza, Pastaza Province and a southern clade from Sardinayacu and Bosque Protector Abanico, Morona Santiago Province; the uncorrected pairwise $p$-genetic distances between these clades range from $1.2 \%$ to $1.4 \%$.

\section{Morphometric analysis}

MANOVA results showed no sexual dimorphism (after removing size effects) on the new species and $P$. petersi. The PCA show broad overlap in morphometric space between both species (Fig. 2). PC I (49.5\%) had high load- ings on head width, head length, and tibia length while PC II (21.5\%) had high loading on tympanum diameter. Both principal components explained $71.0 \%$ of the morphometric variation (Table 2).

\section{Systematic account}

The differences in advertisement calls (see Comparisons with other Species section), the branch lengths in the phylogeny, and genetic distances indicate that the new species, in fact, represents a different species from $P$. petersi (see below). In the following section, we update the species content of the Pristimantis lacrimosus group and describe the new species. 


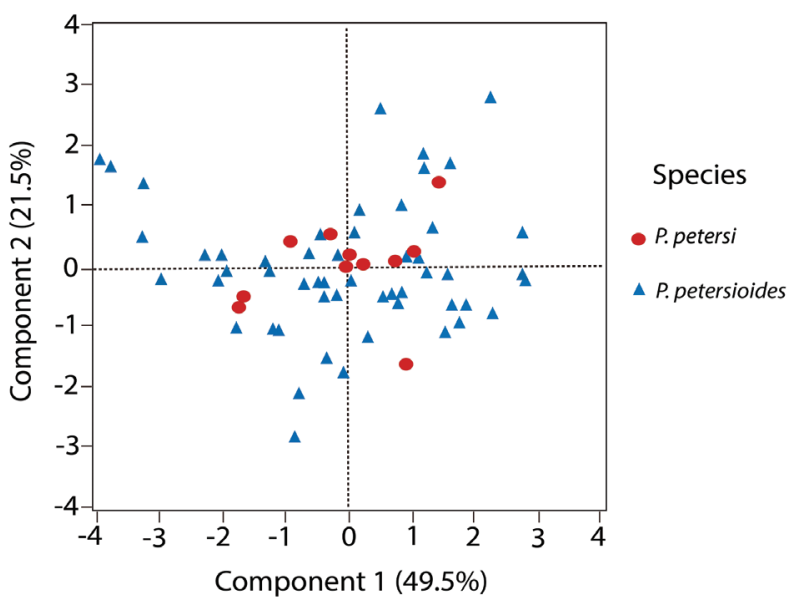

Figure 2. Principal components 1 and 2 from analysis of five size-corrected morphological variables. See Table 2 for character loadings on each component.

Table 2. Character loadings, eigenvalues, and percentage of explained variance for Principal Components (PC) I-II. The analysis was based on the residuals of morphometric variables of adult P. petersioides sp. nov. and P. petersi. Bold figures indicate highest loadings.

\begin{tabular}{lcc}
\hline \multirow{1}{*}{ Variable } & \multicolumn{2}{c}{ Character loading } \\
\cline { 2 - 3 } & PC I & PC II \\
\hline Tibia length & $\mathbf{0 . 7 8 5 5}$ & -0.3038 \\
Foot length & 0.7066 & 0.0834 \\
Head length & $\mathbf{0 . 7 8 7 3}$ & 0.2181 \\
Head width & $\mathbf{0 . 8 3 3 2}$ & 0.2434 \\
Tympanum & -0.2087 & $\mathbf{0 . 9 3 3 4}$ \\
Eigenvalues & 4.9483 & 2.1547 \\
$\%$ & 49.48 & 21.54 \\
\hline
\end{tabular}

\section{Pristimantis lacrimosus species group}

Content. We include all the descendants from the most recent common ancestor of $P$. eremitus and $P$. lacrimosus according to Ron et al. 2020. We exclude Pristimantis eugeniae from this group because it belongs to the sister clade of $P$. lacrimosus species group. We also include $P$. degener which is sister to $P$. subsigillatus and the new species.

According to our findings and those of Ron et al. 2020, the Pristimantis lacrimosus group comprises 39 species (species included in the phylogeny are marked with an asterisk): *P. acuminatus (Shreve, 1935), *P. amaguanae Ron, Carrión, Caminer, Sagredo, Navarrete, Ortega, Varela-Jaramillo, Maldonado-Castro \& Terán, 2020, *P. aureolineatus (Guayasamin, Ron, Cisneros-Heredia, Lamar \& McCracken, 2006), *P. bromeliaceus (Lynch, 1979), P. calima Ospina-Sarria \& Duellman, 2019, *P. crucifer (Boulenger, 1899), *P. degener (Lynch \& Duellman, 1997), P. deyi Lehr, Gregory \& Catenazzi, 2013, *P. ecuadorensis Guayasamin, Hutter, Tapia, Culebras, Peñafiel, Pyron, Morochz, Funk \& Arteaga-Navarro, 2017, *P. enigmaticus Ortega-Andrade, Rojas-Soto, Valencia, Espinosa de los Monteros, Morrone, Ron \& Cannatella, 2015, *P. eremitus (Lynch, 1980), *P. galdi Jiménez de la Espada, 1870,
*P. lacrimosus (Jiménez de la Espada, 1875), P. latericius Batallas \& Brito, 2014, *P. limoncochensis Ortega-Andrade, Rojas-Soto, Valencia, Espinosa de los Monteros, Morrone, Ron \& Cannatella, 2015, *P. mendax (Duellman, 1978), *P. mindo Arteaga, Yanez-Munoz \& Guayasamin, 2013, *P. moro (Savage, 1965), *P. nankints Ron, Carrión, Caminer, Sagredo, Navarrete, Ortega, Varela-Jaramillo, Maldonado-Castro \& Terán, 2020, *P. nyctophylax (Lynch ,1976), *P. olivaceus (Köhler, Morales, Lötters, Reichle \& Aparicio, 1998), *P. omeviridis Ortega-Andrade, Rojas-Soto, Valencia, Espinosa de los Monteros, Morrone, Ron \& Cannatella, 2015, *P. ornatissimus (Despax, 1911), $P$. padiali Moravec, Lehr, Pérez-Peña, López, Gagliardi-Urrutia \& Arista-Tuanama, 2010, P. pardalinus (Lehr, Lundberg, Aguilar and von May, 2006), *P. petersi (Lynch \& Duellman, 1980), *P. petersioides sp. nov. (herein), *P. pluvialis Shepack, von May, Ttito, \& Catenazzi, 2016, $P$. pseudoacuminatus (Shreve, 1935), *P. romeroae Ron, Carrión, Caminer, Sagredo, Navarrete, Ortega, Varela-Jaramillo, Maldonado-Castro \& Terán, 2020, P. royi (Morales, 2007), *P. pulchridormientes Chávez \& Catenazzi, 2016, *P. schultei (Duellman, 1990), *P. subsigillatus (Boulenger, 1902), *P. tantanti (Lehr, Torres-Gastello \& Suárez-Segovia, 2007), P. tayrona (Lynch \& Ruiz-Carranza, 1985), P. waoranii (McCracken, Forstner \& Dixon, 2007), P. zimmermanae (Heyer \& Hardy, 1991), and *P. zorro Rivera-Correa \& Daza 2020.

Distribution. The Pristimantis lacrimosus group is distributed in Central America, the Guianan Shield, Pacific Basin of Ecuador, and the Amazon Basin. Its species richness peaks in the Ecuadorian Andes $(n=19)$ and Amazon basin of Ecuador and Peru $(n=14)$.

Remarks. We refrain from assigning Pristimantis sneiderni (Ospina-Sarria and Duellman 2019) to the Pristimantis lacrimosus group due to the lack of molecular evidence and following Ron et al. (2020).

\section{Pristimantis petersioides sp. nov.}

http://zoobank.org/F2204639-4B59-4071-A033-5BE637144BEE

Eleutherodactylus petersi Lynch \& Duellman 1980 (in part)

Pristimantis petersi Batallas \& Brito 2016

Pristimantis petersi Brito et al. 2017

Holotype. (Figs 3, 4) QCAZ58939, adult female from Ecuador, Morona Santiago Province, Sangay National Park, Sardinayacu $\left(2.0983^{\circ} \mathrm{S}, 78.1555^{\circ} \mathrm{W}\right), 1406 \mathrm{~m}$. Found in amplexus with QCAZ58940. collected by Daniel Rivadeneira and Santiago R. Ron on 21 January 2015.

Paratypes (54: 39 adult males, 15 adult females). All individuals are adults unless otherwise noticed. All from Ecuador. Morona Santiago Province: Sangay National Park: QCAZ58871, female, QCAZ58944, male from Río Volcán $\left(2.1008^{\circ} \mathrm{S}, 78.1559^{\circ} \mathrm{W}, 1345 \mathrm{~m}\right)$, collected by Daniel Rivadeneira, David Velalcázar, Javier Pinto, Francy Mora, Darwin Nuñez, Juan Sanchez, and Andrea Correa; QCAZ58936, 58939, QCAZ58941, females, QCAZ58940, 58942-43, males from Refuge 

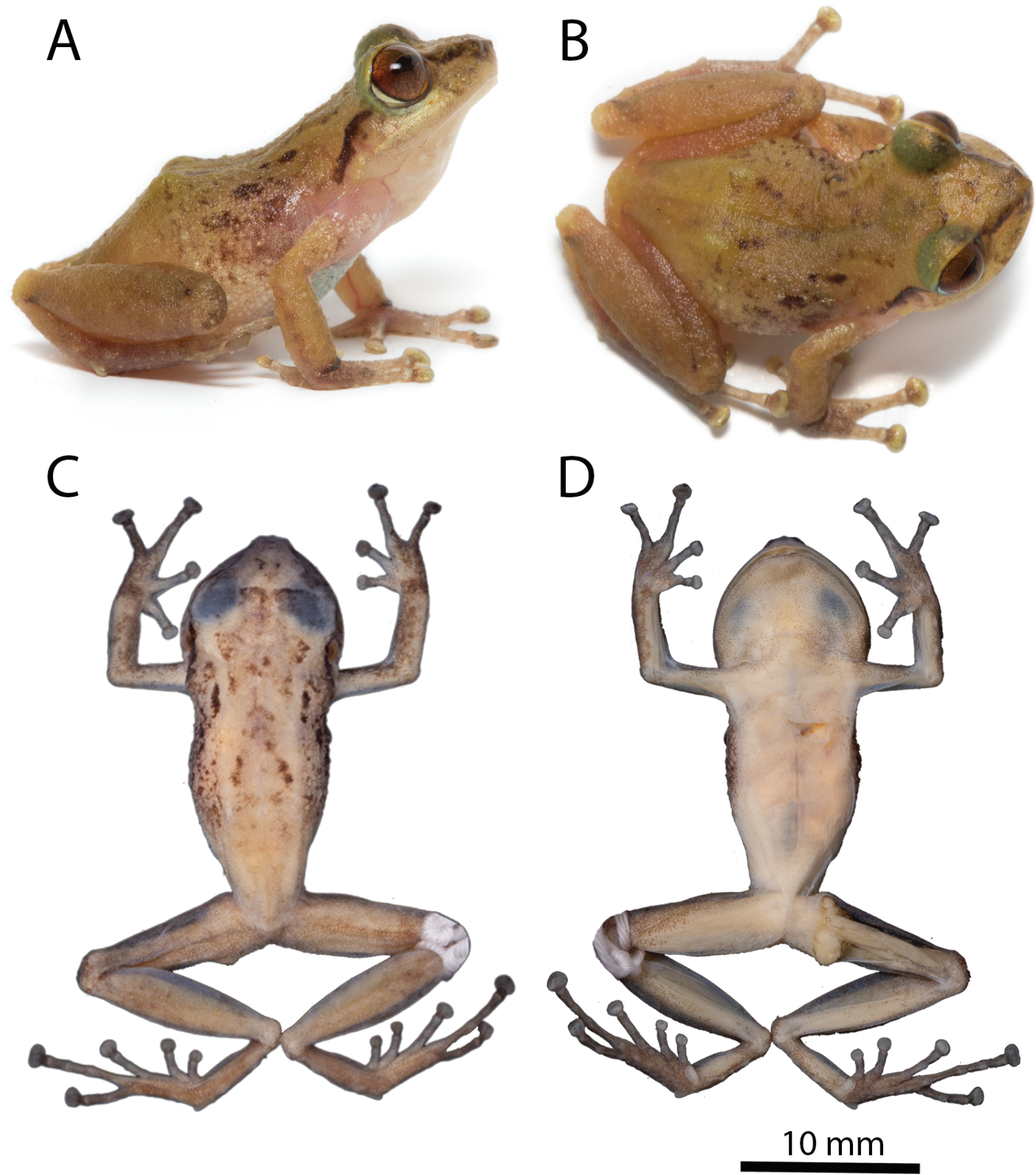

Figure 3. Holotype of Pristimantis petersioides sp. nov. QCAZ58939, adult female, SVL $=22.02 \mathrm{~mm}$. Sangay National Park, Sardinayacu, Ecuador. A lateral view of live individual, B dorsal view of live individual, C dorsal view of preserved individual, D ventral view of preserved individual. Photographs A, B by Juan Carlos Sánchez, C, D by Julio C. Carrión-Olmedo

$1\left(2.0988^{\circ} \mathrm{S}, 78.1561^{\circ} \mathrm{W}, 1406 \mathrm{~m}\right)$, QCAZ58937-38, males from Chimerella lagoon $\left(2.0885^{\circ} \mathrm{S}, 78.2069^{\circ} \mathrm{W}\right.$, $1650 \mathrm{~m}$ ) collected by Daniel Rivadeneira, Francy Mora, Juan Sánchez and Andrea Correa; QCAZ58881, 58950, females, QCAZ58949 male from the proximities of Cormorant lagoon $\left(2.0738^{\circ} \mathrm{S}, 78.2195^{\circ} \mathrm{W}, 1835 \mathrm{~m}\right)$ collected by Javier Pinto, David Velalcázar and Darwin Nuñez, QCAZ58880, 58951, males from El Enmascarado lagoon $\left(2.0600^{\circ} \mathrm{S}, 78.2207^{\circ} \mathrm{W}, 1796 \mathrm{~m}\right)$ collected by Javier Pinto, David Velalcázar and Darwin Nuñez. in January
2015. QCAZ59166, female, QCAZ59167, 58945-48, males from Refuge $3\left(2.0757^{\circ} \mathrm{S}, 78.2157^{\circ} \mathrm{W}, 1724 \mathrm{~m}\right)$, collected by Santiago Ron, Diego Paucar, Pablo Venegas, Pamela Baldeón, Marcel Caminer and Kunam Nucirquia; QCAZ59169-71, males from Cormorant lagoon $\left(2.0738^{\circ} \mathrm{S}, 78.2195^{\circ} \mathrm{W}, 1835 \mathrm{~m}\right)$, collected by Santiago Ron, Diego Paucar, Pablo Venegas, Pamela Baldeón, Marcel Caminer and Kunam Nucirquia, in February 2015. Pastaza Province: QCAZ53227, female, from Anzu river $\left(1.4177^{\circ} \mathrm{S}, 78.0485^{\circ} \mathrm{W}, 1272 \mathrm{~m}\right.$ a.s.l), col- 


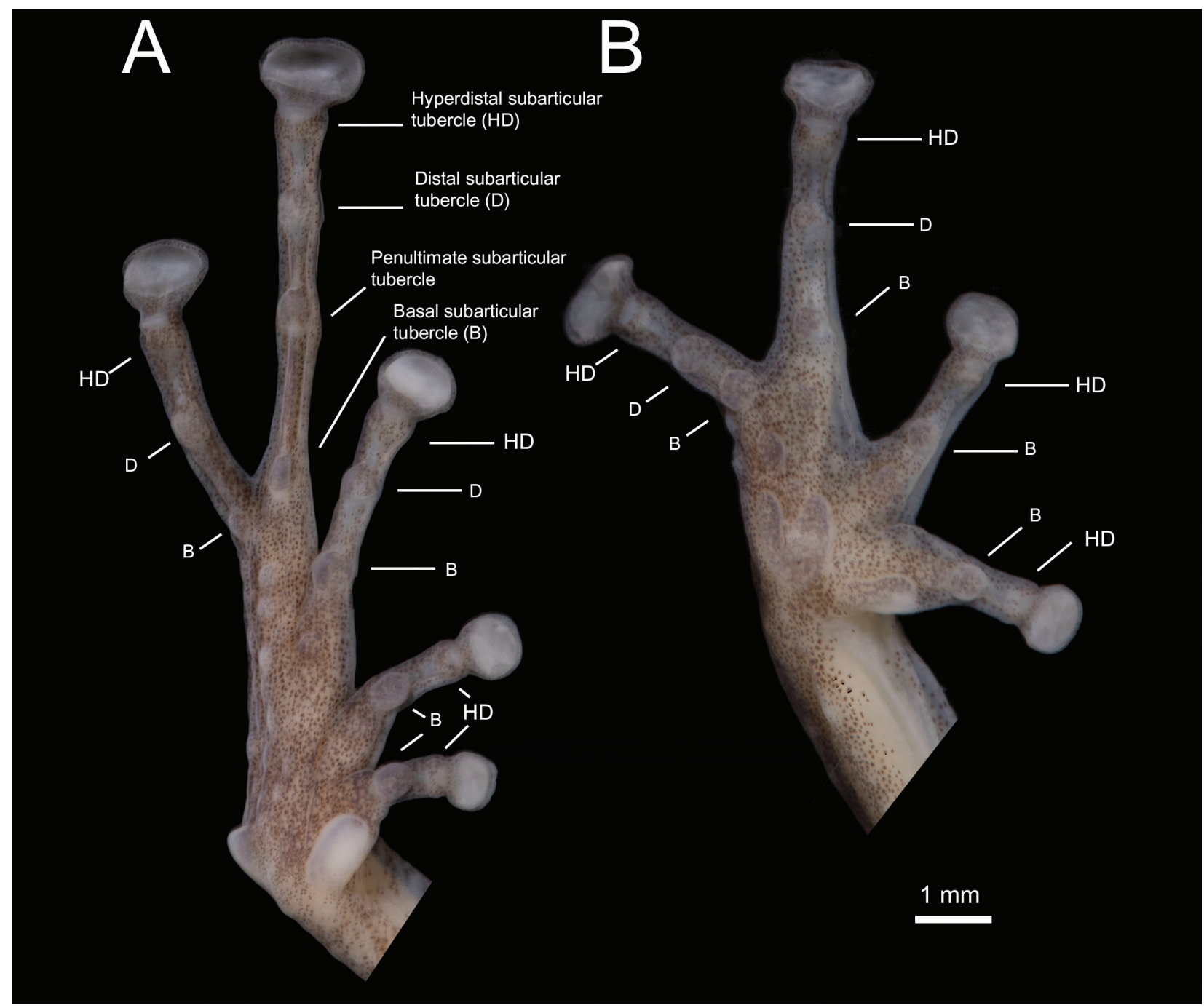

Figure 4. Hand and foot of the holotype of Pristimantis petersioides sp. nov. QCAZ58939, adult female. Ventral views of right foot A and right hand $\mathbf{B}$. Abbreviations: $\mathrm{B}=$ basal, $\mathrm{D}=$ distal, $\mathrm{HD}=$ hyperdistal. Photographs by Julio C. Carrión-Olmedo.

lected by Mauricio Ortega in May 2012. Llanganates National Park: QCAZ45846-50, 45892, 45898, males, from Challuwa Yacu river, Ankaku Reserve $\left(1.2792^{\circ} \mathrm{S}\right.$, $\left.78.0779^{\circ} \mathrm{W}, 2300 \mathrm{~m}\right)$ collected by Elicio Tapia and Silvia Aldás in October 2009; QCAZ66553, male, from Ankaku Reserve $\left(1.2770^{\circ} \mathrm{S}, 78.0698^{\circ} \mathrm{W}, 2216 \mathrm{~m}\right)$ collected by Diego Almeida, Santiago Guamán, Darwin Nuñez, María Navarrete, Verónica Andrade, Angel Alvarado, Fernando Alvarado in January 2017, QCAZ59625, male, from Nuchimingue river $\left(1.3626^{\circ} \mathrm{S}, 78.0582^{\circ} \mathrm{W}, 1350 \mathrm{~m}\right)$; QCAZ59456, male, from Yurugyacu river $\left(1.3560^{\circ} \mathrm{S}\right.$, $\left.78.0592^{\circ} \mathrm{W}, 1354 \mathrm{~m}\right)$; QCAZ59451, 59467-68, 59479, males, from Zarentza community $\left(1.3556^{\circ} \mathrm{S}, 78.0597^{\circ} \mathrm{W}\right.$, 1363 m); QCAZ59458-59, females from near Yurugyacu river $\left(1.3527^{\circ} \mathrm{S}, 78.0596^{\circ} \mathrm{W}, 1354 \mathrm{~m}\right)$; QCAZ59457, 59465 females, QCAZ59454-55, 59462-63, 59466, males from the ravines of Yurugyacu river $\left(1.3523^{\circ} \mathrm{S}\right.$, $\left.78.0597^{\circ} \mathrm{W}, 1419 \mathrm{~m}\right)$; QCAZ59470, 59472, females, QCAZ59471, 59473, males from Gustavo Ushpa house trail to Yurugyacu river $\left(1.3430^{\circ} \mathrm{S}, 78.0574^{\circ} \mathrm{W}, 1221 \mathrm{~m}\right)$; QCAZ59461, female, from La paila waterfall $\left(1.3397^{\circ} \mathrm{S}\right.$, $\left.78.0594^{\circ} \mathrm{W}, 1360 \mathrm{~m}\right)$ collected by Daniel Rivadeneira,
Francy Mora, Juan Carlos Sánchez, David Velalcázar, Darwin Nuñez and Javier Pinto in February 2015.

Referred specimens. Napo Province: QCAZ46159, male, from Salcedo-Tena highway, km $60\left(0.9847^{\circ} \mathrm{S}\right.$, $78.1928^{\circ} \mathrm{W}, 2253 \mathrm{~m}$ ), collected by Elicio Tapia and Fernando Núñez in November 2009. Pastaza Province: QCAZ59452-53, 59460, 59464, juveniles from the ravines of Yurugyacu river $\left(1.3523^{\circ} \mathrm{S}, 78.0597^{\circ} \mathrm{W}, 1419 \mathrm{~m}\right)$ collected by Daniel Rivadeneira, Francy Mora, Juan Carlos Sánchez, David Velalcázar, Darwin Nuñez and Javier Pinto in February 2015.

Suggested common name. English: Sardinayacu's Rain Frog. Spanish: Cutín de Sardinayacu

Diagnosis. The assignment of the new species to the genus Pristimantis is based on the phylogeny (Fig. 1). Pristimantis petersioides sp. nov. is characterized by the following combination of characters: (1) Skin on dorsum smooth to shagreen with or without scattered small tubercles, head with or without one interorbital small tubercle, skin of venter shagreened to weakly areolate; discoidal fold present, ill-defined; dorsolateral folds absent; (2) tympanic membrane and tympanic annulus present, round, its 
length $2 / 5$ to $1 / 2$ of eye diameter; its upper border weakly concealed by inconspicuous supratympanic fold; (3) snout rounded to truncate in dorsal view, truncate in lateral view, bearing a small rostral papilla; (4) interorbital space flat, broader than upper eyelid; upper eyelid with one distinct subconical tubercle surrounded by lower, indistinct rounded tubercles; cranial crests absent; (5) vomerine odontophores low to prominent, oblique, moderately separated, posteromedial to choanae; (6) males with prominent, subgular vocal sac and vocal slits; (7) first finger shorter than second; all fingers long, discs broadly expanded, rounded to truncate; all fingers bearing a hyperdistal tubercle (Fig. 4B); (8) fingers with narrow lateral fringes; (9) few ulnar tubercles; (10) no knee and heel tubercles, outer tarsal fold bearing one to three indistinct tubercles; (11) two metatarsal tubercles, inner oval, $3 \mathrm{x}$ the size of outer conical and elliptical metatarsal tubercle; supernumerary plantar tubercles numerous; (12) all toes with hyperdistal tubercles; toes with narrow lateral fringes; basal toe webbing absent, discs broadly expanded, Toe IV much longer than Toe III (disc on Toe III reaches proximal edge of penultimate subarticular tubercle on Toe IV, disc on Toe V exceeds the distal edge of penultimate subarticular tubercle on Toe IV), discs as expanded as those on fingers (Fig. 4A); (13) SVL $22.8 \pm 1.4 \mathrm{~mm}(20.4-24.8 \mathrm{~mm} ; n=15)$ in females, $18.5 \pm$ $1.5 \mathrm{~mm}(15.8-23.9 \mathrm{~mm} ; n=39)$ in males.

Comparison with other species. Color comparisons are based on digital photos of live specimens, unless otherwise noted. Pristimantis petersioides sp. nov. is most similar to other species of the $P$. lacrimosus group, especially P. petersi (Lynch \& Duellman, 1980), P. bromeliaceus (Lynch, 1979), P. lacrimosus (Jiménez de la Espada, 1875), P. schultei (Duellman, 1990), P. pastazensis (Andersson, 1945), and P. rhodostichus (Duellman \& Pramuk, 1999) (Fig. 5). Pristimantis petersioides sp. nov. can only be distinguished from $P$. petersi by differences in advertisement calls. Call duration is shorter in $P$. petersioides sp. nov. $0.25 \mathrm{~s}$ (Table 3; 0.19-0.32 s; $\mathrm{n}=3$ ) than in P. petersi, $0.42 \mathrm{~s}(0.37-0.46 \mathrm{~s} ; \mathrm{n}=2)$. Dominant frequencies also differ: $4430.79 \mathrm{~Hz}(4122-4837.22 \mathrm{~Hz}$; n $=3$ ) in P. petersioides sp. nov. and $3956.75 \mathrm{~Hz}(3836.67-$ $4076.84 \mathrm{~Hz} ; \mathrm{n}=2)$ in $P$. petersi. Call duration and dominant frequency are static call traits and, therefore, are less variable within species and most reliable to define species boundaries (Köhler et al. 2017). Crucially, the new species and $P$. petersi are not sister species and are separated by large genetic distances: uncorrected pairwise $p$-genetic distances for gene $16 \mathrm{~S}$ range from $7.9 \%$ to $8.4 \%$. Pristimantis petersioides sp. nov. can be distinguished from $P$. bromeliaceus by snout shape (rounded to truncate in $P$. petersioides sp. nov. vs. subacuminate in P. bromeliaceus), texture of ventral skin (weakly areolate in $P$. petersioides sp. nov. vs. coarsely areolate in $P$. bromeliaceus), iris coloration (reddish coppery in $P$. petersioides sp. nov. vs. brown flecked with gold or bronze in P. bromeliaceus), and by having an eyelid with one conical tubercle surrounded by lower tubercles (two to three non-conical tubercles in P. bromeliaceus). Pristimantis petersioides sp. nov. differs from P. lacrimosus (Jiménez de la Espada, 1875) in dorsal coloration (dark greenish brown to pale yellowish green in $P$. petersioides sp. nov. vs. golden brown in $P$. lacrimosus), presence of eyelid tubercles and narrow lateral fringes (both absent in P. lacrimosus), and size of outer metatarsal tubercle $(3 \times$ bigger than the inner metatarsal tubercle in $P$. petersioides sp. nov. vs. 5-6× bigger in $P$. lacrimosus). Pristimantis petersioides sp. nov. is also similar to P. rhodostichus and P. schultei from Peru and Ecuador. It can be distinguished from both by snout shape in dorsal view (rounded to truncate in $P$. petersioides sp. nov. vs. long acuminate in $P$. rhodostichus [Duellman \& Pramuk, 1999] and acuminate in P. schultei). It can be further distinguished from P. schultei by lacking heel tubercles (present in P. schultei), and from $P$. rhodostichus by lacking red markings on the dorsum (present in P. rhodostichus, Duellman \& Pramuk, 1999). Additionally, P. petersioides sp. nov. differs from P. pastazensis (Andersson, 1945) by snout shape in dorsal view (rounded to truncate in $P$. petersioides sp. nov. vs. subacuminate in $P$. pastazensis, Andersson, 1945), tubercles on upper eyelid (one distinct conical tubercle surrounded by lower, indistinct rounded tubercles in $P$. petersioides sp. nov. vs. several minute rounded tubercles in P. pastazensis, Andersson 1945), and skin of venter (weakly areolate in $P$. petersioides sp. nov. vs. coarsely granular in P. pastazensis, Andersson 1945). For further comparison see Table 4.

Description of the holotype. Adult female (QCAZ58939). Measurements (in mm): SVL 22.02; tibia length 12.07; foot length 10.72; head length 8.82 ; head width 9.09 ; eye diameter 2.96; tympanum diameter 1.35; interorbital distance 2.52; upper eyelid width 2.44; internarial distance 1.59; eye-nostril distance 2.59; tympanum-eye distance 0.71 . Body slender; head slightly wider than long, wider than body; snout rounded to truncate with rostral papilla in dorsal view, truncate in lateral profile; canthus rostralis distinct, slightly curved in dorsal view; loreal region concave; interorbital space flat, no cranial crests; eye large, protuberant; upper eyelid about $97 \%$ of interorbital distance, bearing one subconical tubercle. Tympanic membrane and annulus distinct, rounded, with inconspicuous supratympanic fold, partially obscuring anterodorsal edge; horizontal diameter of tympanum about $13 \%$ of head length, separated from eye by a distance about one half tympanum length; choanae large, rounded, not concealed by palatal shelf of maxillary arc; dentigerous processes of vomers prominent, oblique, bearing a transverse row of five teeth; tongue big, elliptical, posterior border slightly notched, $40 \%$ of the anterior surface adherent to floor of mouth. Skin on dorsum smooth to shagreen; dorsolateral folds absent; skin on upper flanks bearing scattered low tubercles; skin on belly weakly areolate; skin on throat and chest smooth; discoidal fold ill-defined; skin in upper cloacal region shagreen. Forearms slender bearing low antebrachial tubercle and one subconical ulnar tubercle at the distal half of the forearm; fingers large and slender, all with broadly 


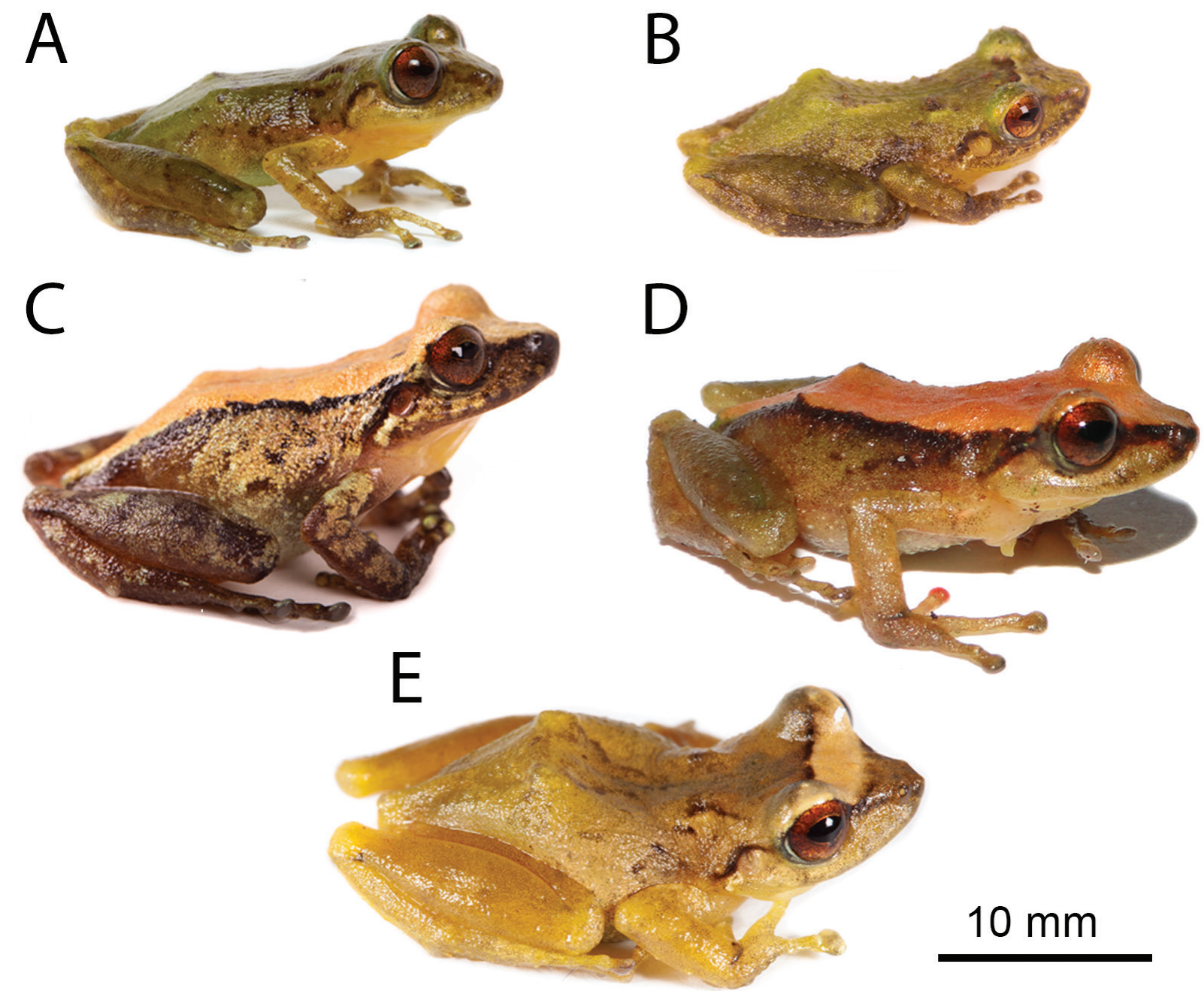

Figure 5. Live specimens of Pristimantis petersioides sp. nov. and most similar species. A Pristimantis petersioides sp. nov., QCAZ58938, adult male (SVL $17.99 \mathrm{~mm}$ ), B Pristimantis petersi, QCAZ63455, adult male (SVL $16.49 \mathrm{~mm}$ ), C Pristimantis sp., QCAZ62940, adult male (SVL $23.45 \mathrm{~mm}$ ), D Pristimantis bromeliaceus, QCAZ56454, adult male (SVL $21.93 \mathrm{~mm}$ ) E Pristimantis schultei, QCAZ51551, adult male (SVL $24.60 \mathrm{~mm}$ ). Photographs by Juan Carlos Sánchez A, by David Velalcázar B, by Valeria Chasiluisa C, by Jorge Brito D, by Diego Paucar $\mathbf{E}$.

expanded pads, all fingers with discs; fingers bearing narrow lateral fringes; relative lengths of fingers I $<$ II $<$ IV $<$ III; three subarticular tubercles on finger III (Fig. 4B), the most distal we refer as hyperdistal, all the tubercles well defined, round in ventral and lateral view; several supernumerary tubercles present, prominent at the base of the fingers and lower, indistinct at the palmar surface; palmar tubercle bifid, heart-shaped, about the same length and twice the width of elliptical thenar tubercle (Fig. 4B).

Hindlimbs slender; tibia length about $55 \%$ of SVL; upper surfaces of hindlimbs smooth; foot length about $48 \%$ of SVL, posterior surfaces of thighs smooth, ventral surfaces of thighs slightly areolate; knee and heel lacking tubercles; outer surface of tarsus bearing three low, inconspicuous tubercles, equally distributed along tarsus; toes bearing narrow lateral fringes; webbing between toes absent; discs on toes broadly expanded as those on fingers, rounded; relative lengths of toes: I $<$ II $<$ III $<$ V $<$ IV; Toe V much longer than Toe III (disc on Toe III reaches proximal edge of penultimate subarticular tubercle on Toe IV, disc on Toe $\mathrm{V}$ exceeds the distal edge of penultimate subarticular tubercle on Toe IV), subarticular tubercles rounded, simple, elevated; plantar surface with low supernumerary tubercles, bearing four subarticular tubercles (Fig. 4A), inner metatarsal tubercle prominent, elliptical, approximately $3 \mathrm{x}$ size of oval and conical outer metatarsal tubercle (Fig. 4A).

Color of holotype in preservative. (Fig. 3C, D) Background color pale grayish cream with scattered, irregular dark brown chevrons, head bearing dark brown supratympanic and canthal stripe, upper lip bearing ill-defined stripe formed by irregular dark brown dots; upper flanks bearing dark brown, irregular flecks and blotches densely distributed; venter, ventral surfaces of forearms and hindlimbs pale creamy white, chest and throat with diminutive dark brown dots uniformly distributed (visible under magnification); ventral surfaces of hands and foot with dense minute dark brown dots, posterior surfaces 
Table 3. Quantitative and qualitative characteristics of the advertisement call of Pristimantis petersioides sp. nov. from two localities: Sardinayacu, Morona Santiago Province $\left(2.0983^{\circ} \mathrm{S}, 78.1155^{\circ} \mathrm{W}, 1345 \mathrm{~m}\right)$ and Yurugyacu river, Llanganates National Park, Pastaza Province, Ecuador $\left(1.3524^{\circ} \mathrm{S}, 78.0597^{\circ} \mathrm{W}, 1419 \mathrm{~m}\right)$ in comparison with Pristimantis petersi from Cocodrilos, Napo Province $\left(0.6710^{\circ} \mathrm{S}, 77.7927^{\circ} \mathrm{W}, 1575 \mathrm{~m}\right)$. Mean is given with range in parentheses. Because the dominant frequency is on the first harmonic, it equals the fundamental frequency.

\begin{tabular}{|c|c|c|c|c|c|}
\hline & $\begin{array}{c}\begin{array}{c}\text { Pristimantis petersioides } \\
\text { sp. nov. }\end{array} \\
\text { QCAZ58940 }\end{array}$ & $\begin{array}{c}\begin{array}{c}\text { Pristimantis petersioides } \\
\text { sp. nov. }\end{array} \\
\text { QCAZ59466 }\end{array}$ & $\begin{array}{c}\begin{array}{c}\text { Pristimantis petersioides } \\
\text { sp. nov. }\end{array} \\
\text { (not collected) }\end{array}$ & $\begin{array}{l}\text { Pristimantis petersi } \\
\text { (not collected) }\end{array}$ & $\begin{array}{l}\text { Pristimantis petersi } \\
\text { (not collected) }\end{array}$ \\
\hline Calls analyzed & 47 & 37 & 13 & 4 & 9 \\
\hline Call duration (s) & $0.19(0.11-0.32)$ & $0.32(0.16-0.39)$ & $0.25(0.19-0.34)$ & $0.46(0.41-0.49)$ & $0.37(0.31-0.44)$ \\
\hline Call rate (calls/minute) & $11.26(1.77-18.40)$ & $25.78(4.52-35.14)$ & $22.64(12-17.88)$ & $4.24(1.86-6.62)$ & $9.04(2.17-33.18)$ \\
\hline Call interval (s) & $6.21(3.03-33.66)$ & $2.49(1.37-13.09)$ & $2.44(1.82-3.05)$ & $20.16(8.59-31.73)$ & $11.13(1.41-27.20)$ \\
\hline Call rise time (s) & $0.03(0.021-0.036)$ & $0.013(0.011-0.019)$ & $0.008(0.004-0.015)$ & $0.064(0.04-0.12)$ & $0.0107(0.07-0.18)$ \\
\hline Notes per call & 1 & 1 & 1 & 1 & 1 \\
\hline Fundamental frequency $(\mathrm{Hz})$ & $4837.22(4373.4-5092.6)$ & $4122(3644.5-4382.8)$ & $4333.1(4295.9-4392.8)$ & $3846.7(3820.3-3890.6)$ & $4076.8(3914.1-4242.2)$ \\
\hline Dominant frequency $(\mathrm{Hz})$ & $1^{\text {st }}$ harmonic & $1^{\text {st }}$ harmonic & $1^{\text {st }}$ harmonic & $1^{\text {st }}$ harmonic & $1^{\text {st }}$ harmonic \\
\hline
\end{tabular}

Table 4. Qualitative morphological characters of species most similar to P. petersioides sp. nov.

\begin{tabular}{|c|c|c|c|c|c|c|c|c|c|c|}
\hline & $\begin{array}{c}\text { Maximun size } \\
\text { in females }\end{array}$ & $\begin{array}{c}\text { Eyelid } \\
\text { tubercle }\end{array}$ & $\begin{array}{c}\text { Discoidal } \\
\text { fold }\end{array}$ & $\begin{array}{c}\text { Dorsal snout } \\
\text { shape }\end{array}$ & $\begin{array}{c}\text { Lateral snout } \\
\text { shape }\end{array}$ & TY/ED & $\begin{array}{c}\text { Knee } \\
\text { tubercle }\end{array}$ & $\begin{array}{c}\text { Heel } \\
\text { tubercle }\end{array}$ & Dorsum & Data source \\
\hline P. bromeliaceus & $27.2 \mathrm{~mm}$ & 2-3 non conical & prominent & subacuminate & pointed & $1 / 4$ to $2 / 5$ & small wart & conical & smooth & Lynch, 1979 \\
\hline P. lacrimosus & $32.5 \mathrm{~mm}$ & absent & evident & rounded & rounded & $3 / 10$ & absent & absent & finely shagreen & $\begin{array}{l}\text { Jiménez de la } \\
\text { Espada, } 1875\end{array}$ \\
\hline P. petersi & $21.1 \mathrm{~mm}$ & conical & absent & rounded & truncate & $3 / 5$ to $1 / 2$ & absent & absent & smooth & Herein \\
\hline $\begin{array}{l}\text { P. petersioides } \\
\text { sp. nov. }\end{array}$ & $24.8 \mathrm{~mm}$ & conical & ill-defined & $\begin{array}{l}\text { rounded to } \\
\text { truncate }\end{array}$ & truncate & $2 / 5$ to $1 / 2$ & absent & absent & $\begin{array}{l}\text { smooth to } \\
\text { shagreen }\end{array}$ & Herein \\
\hline P. rhodostichus & $29.5 \mathrm{~mm}$ & several low & prominent & $\begin{array}{l}\text { long, } \\
\text { acuminate }\end{array}$ & acutely rounded & $2 / 5$ & absent & absent & finely shagreen & $\begin{array}{l}\text { Duellman and } \\
\text { Pramuk, } 1999\end{array}$ \\
\hline P. schultei & $34.0 \mathrm{~mm}$ & several low & not evident & acuminate & $\begin{array}{c}\text { inclined } \\
\text { posteroventrally }\end{array}$ & $2 / 5$ to $1 / 2$ & absent & $\begin{array}{c}\text { several } \\
\text { low }\end{array}$ & shagreen & $\begin{array}{l}\text { Duellman, } \\
1990\end{array}$ \\
\hline
\end{tabular}

of thighs pale cream to dark brown; iris reddish coppery with fine, dense, black reticulation.

Color of holotype in life. (Fig. 3A, B) Dorsal surfaces yellowish green with scattered, irregular dark brown chevrons; canthal stripe and supratympanic fold black, upper flanks pale cream with dark brown irregular flecks and blotches; venter creamy white; axils pinkish white; ventral surfaces of limbs, thighs yellowish green; iris reddish copper with dark bronze faint horizontal streak and thin irregular black reticulations.

Variation in preservative. (Fig. 6) Adult males $(15.79-23.93 \mathrm{~mm})$ are smaller than adult females $(20.42-$ $24.81 \mathrm{~mm}$ ). See Table 5 for measurements of the type series. Males bearing vocal slits and prominent subgular sac, lacking nuptial pads. Skin tuberculation is less noticeable than in live specimens, it can vary from dorsum completely smooth (e.g., QCAZ58943, 59171) to shagreen (e.g., QCAZ59456). Tubercles on flanks remain conspicuous when dorsum is shagreen (e.g., QCAZ59470, 59472) and also upper eyelids tubercles and interorbital tubercle are more evident when dorsum is shagreen or flanks are tuberculated (e.g., QCAZ59456, 59470). Dorsal background coloration in preserved specimens varies from uniform dark brown (e.g., QCAZ58951, 59451, 59461) to pale cream (e.g., QCAZ58881, 58936, 59166). Marks on dorsum varies from scattered, irregular dark brown chevrons that form a triangle extending from the ilium to the scapula (e.g., QCAZ58950, 59468), ill-defined, dark brown flecks and spots (e.g., QCAZ58948, 59472), pale cream middorsal bar from the snout to the cloaca (e.g.,
QCAZ59456), to black dorsolateral stripes suffused with supratympanic stripes (e.g., QCAZ58943, 59171), with or without dark interorbital bar.

Variation in life. (Fig. 7). Tuberculation pattern varies from dorsum completely smooth (e.g., QCAZ58943, 58951) to dorsum shagreen (e.g., QCAZ58938, 58939), some individuals bear scattered small tubercles on anterior half of dorsum (e.g., QCAZ58880) or have the dorsum densely tuberculated (e.g., QCAZ59463). When dorsum is tuberculated, flanks and limbs usually bear scattered tubercles more conspicuous than those in the dorsum. Similarly, the interorbital tubercle and upper eyelid tubercles are more prominent when the dorsum is tuberculated. There is extensive variation in dorsal coloration (Fig. 7). Dorsum varies from dark greenish brown (e.g., QCAZ59471), bright orange (e.g., QCAZ58943), olive green (e.g., QCAZ58938), to pale yellowish green (e.g., QCAZ58941). Dark marks on dorsum vary from scattered dark brown flecks to irregular brown chevrons that form a triangle that extends from the ilium to the scapula, to ill-defined, dark brown flecks and spots (e.g., QCAZ58948, 59455). Some individuals bear bright orange blotches limited by dark brown contours (e.g., QCAZ58951, 59458), a bright orange middorsal bar that extends from the snout to the cloaca (e.g., QCAZ59456), black dorsolateral stripes suffused with supratympanic stripes (e.g., QCAZ58943). Bright orange to yellow with a darker contour interorbital stripe or bar may be present (e.g., QCAZ59455, 59458, 59462) or absent (e.g., QCAZ58943, 59456). Snout varies from dark green- 

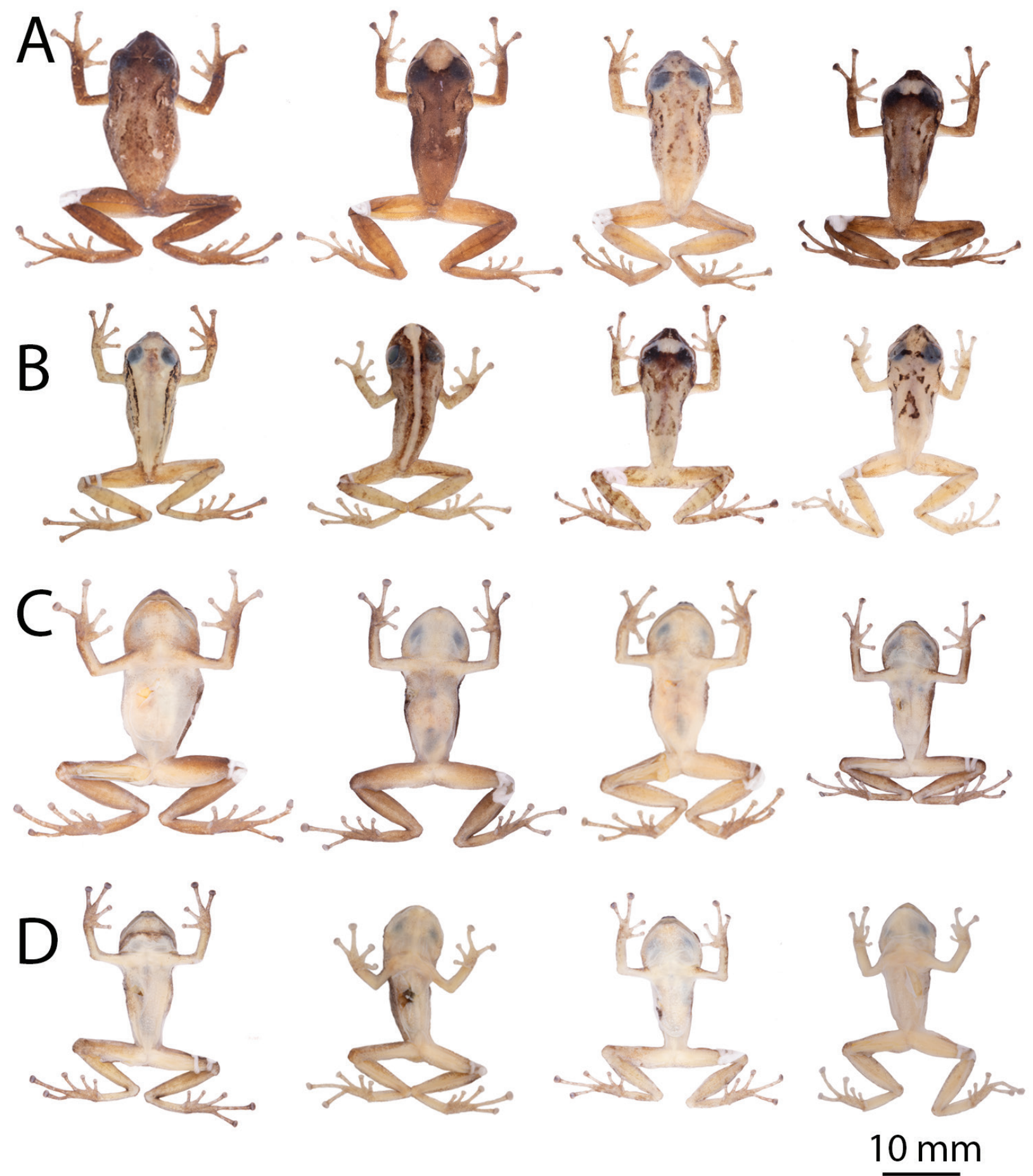

Figure 6. Color variation in preserved individuals of Pristimantis petersioides sp. nov. A Dorsal view (left to right): QCAZ59461(SVL $22.95 \mathrm{~mm}$ ), QCAZ59470 (SVL $22.94 \mathrm{~mm}$ ), QCAZ58939 (SVL $22.02 \mathrm{~mm}$ ), QCAZ58951 (SVL $19.75 \mathrm{~mm}$ ), B Dorsal view (left to right): QCAZ59171 (SVL $19.50 \mathrm{~mm}$ ), QCAZ59456 (SVL $19.05 \mathrm{~mm}$ ), QCAZ59462 (SVL $19.00 \mathrm{~mm}$ ), QCAZ59468 (SVL 18,35 $\mathrm{mm}$ ), C Ventral view of specimens in (A), D Ventral view of specimens in (B). Photographs by Julio C. Carrión-Olmedo.

ish brown, pale yellowish green to bright orange (e.g., QCAZ59455, 59466, 59471).

Advertisement call. Quantitative measurements of the advertisement call of Pristimantis petersioides sp. nov. (QCAZ58940) are shown in Table 3. The call is a metallic click with an average duration of $0.25 \mathrm{~s}$ (0.19-0.32 s; $\mathrm{n}=3$; Fig. 8). The amplitude peak occurs at 20-30 ms and then decreases gradually towards the end (Fig. 8). The calls are repeated at a mean rate of 19.89 calls per minute $(11.26-25.78 ; n=3)$. Three or four harmonics are visible, but most of the energy is located on the first one. The dominant frequency (= fundamental frequency) is $4430.79 \mathrm{~Hz}(4122-4837.22$ $\mathrm{Hz} ; \mathrm{n}=3)$. 
Table 5. Morphometric variables of $P$. petersioides sp. nov. and P. petersi. Mean $\pm \mathrm{SD}$ is given with range in parentheses. All measurements are in millimeters.

\begin{tabular}{|c|c|c|c|c|}
\hline \multirow[t]{3}{*}{ Variable } & \multicolumn{2}{|c|}{ P. petersioides sp. nov. } & \multicolumn{2}{|c|}{ P. petersi } \\
\hline & male & female & male & female \\
\hline & $\mathrm{n}=39$ & $\mathrm{n}=15$ & $\mathrm{n}=10$ & $\mathrm{n}=2$ \\
\hline Snout-vent length & $18.5 \pm 1.5(15.8-23.9)$ & $22.8 \pm 1.4(20.4-24.8)$ & $18.3 \pm 1.7(16.5-22.7)$ & $20.1 \pm 1.4(19.1-21.1)$ \\
\hline Tibia length & $9.8 \pm 0.8(8.3-11.9)$ & $11.7 \pm 1.0(8.5-12.6)$ & $9.6 \pm 0.6(8.6-11.0)$ & $10.7 \pm 1.6(9.6-11.8)$ \\
\hline Foot length & $8.6 \pm 0.9(6,9-10.7)$ & $10.6 \pm 0.7(8.8-11.6)$ & $8.6 \pm 0.7(7.8-10.1)$ & $10.0 \pm 0.3(9.8-10.2)$ \\
\hline Head length & $6.5 \pm 0.6(5.3-7.8)$ & $8.0 \pm 0.6(7.2-9.1)$ & $6.1 \pm 0.5(5.5-7.1)$ & $7.1 \pm 0.5(6.8-7.5)$ \\
\hline Head width & $7.0 \pm 0.6(5.9-8.5)$ & $8.8 \pm 0.5(8.0-9.5)$ & $6.9 \pm 0.5(6.3-8.1)$ & $7.7 \pm 0.4(7.5-8.0)$ \\
\hline Eye diameter & $2.6 \pm 0.2(2.2-3.1)$ & $3.0 \pm 0.3(2.4-3.5)$ & $2.6 \pm 0.2(2.4-3.1)$ & 2.8 \\
\hline Tympanum diameter & $0.9 \pm 0.1(0.7-1.1)$ & $1.1 \pm 0.2(0.8-1.4)$ & $0.9 \pm 0.1(0.7-1.0)$ & $1.1 \pm 0.1(1.0-1.2)$ \\
\hline Interorbital distance & $2.2 \pm 0.2(1.9-2.6)$ & $2.6 \pm 0.2(2.4-3.0)$ & $2.2 \pm 0.1(2.0-2.5)$ & $2.6 \pm 0.2(2.4-2.7)$ \\
\hline Upper eyelid width & $2.2 \pm 0.3(1.6-2.6)$ & $2.6 \pm 0.2(2.3-3.0)$ & $2.1 \pm 0.4(1.7-2.9)$ & 2.27 \\
\hline Internarial distance & $1.4 \pm 0.1(1.2-1.7)$ & $1.7 \pm 0.1(1.5-2.0)$ & $1.5 \pm 0.2(1.3-1.7)$ & $1.6 \pm 0.2(1.4-1.7)$ \\
\hline eye-nostril distance & $1.9 \pm 0.2(1.6-2.5)$ & $2.5 \pm 0.2(2.2-2.8)$ & $2.1 \pm 0.3(1.8-2.9)$ & $2.3 \pm 0.4(2.0-2.6)$ \\
\hline
\end{tabular}
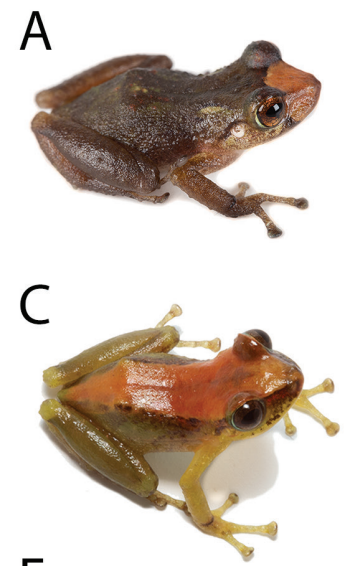

$\mathrm{E}$

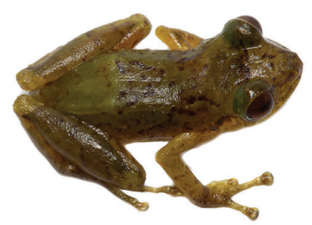

G

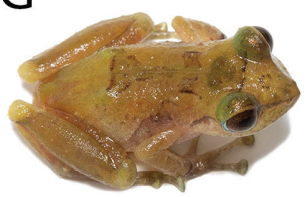

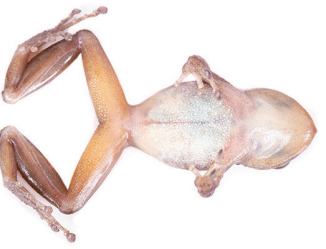
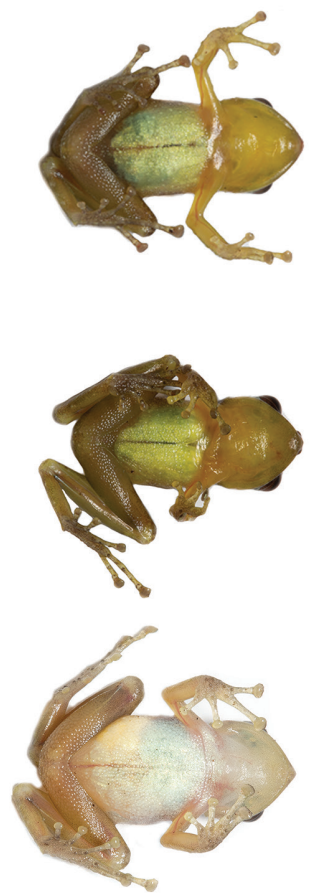
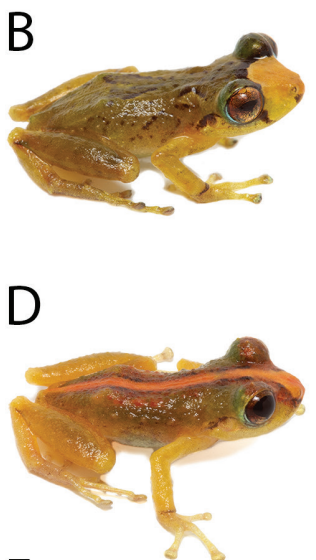

$\mathrm{F}$
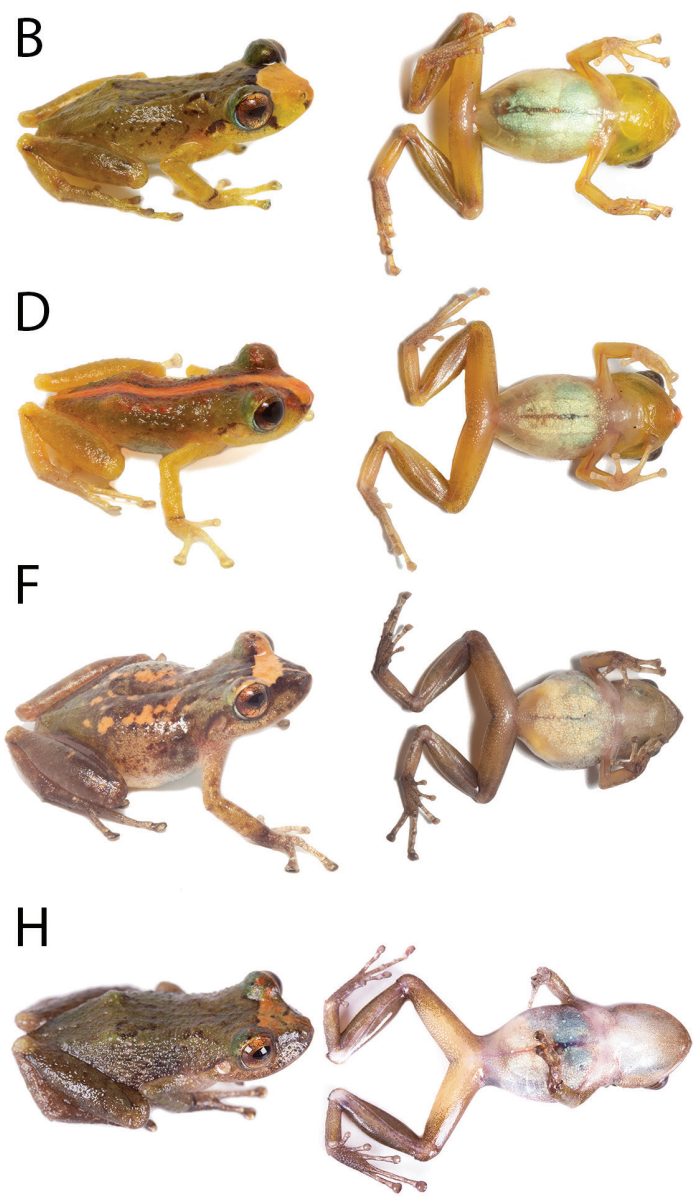

Figure 7. Variation in live adult individuals of Pristimantis petersioides sp. nov. A QCAZ59471 (SVL 17.45 mm), B QCAZ59455 (SVL $18.2 \mathrm{~mm}$ ), C QCAZ58943 (SVL $17.73 \mathrm{~mm}$ ), D QCAZ59456 (SVL $19.05 \mathrm{~mm}$ ), E QCAZ58938 (SVL $17.99 \mathrm{~mm}), \mathbf{F}$ QCAZ59458 (SVL 21.84 mm), G QCAZ58941 (SVL 20.42 mm), H QCAZ59466 (SVL $19.06 \mathrm{~mm}$ ). Dorsolateral view on the left, ventral view on the right. Photographs $\mathbf{A}$ and $\mathbf{H}$ by Santiago R. Ron, B-G by Juan Carlos Sánchez.

Distribution and natural history. Pristimantis petersioides sp. nov. is known from six localities in the eastern Andean slopes of central Ecuador between 1221-2300 m (Fig. 9). It inhabits the Eastern Andean Foothills Forest and Eastern Montane Forest natural regions (as defined by Ron et al. 2019). It has been recorded in primary forest and, less frequently, in secondary forest. Individuals were found during nocturnal surveys, usually perching on ferns, herbs, or Heliconia leaves, branches, or inside bromeliads up to $350 \mathrm{~cm}$ above the ground, usually near water bodies. Three amplectant pairs were found on January and February 2015 in Sardinayacu and Zarentza.

Etymology. The specific epithet is a masculine noun in apposition. The suffix oides is derived from the Greek eidos meaning similar. The name makes reference to the 


\section{Pristimantis petersioides}

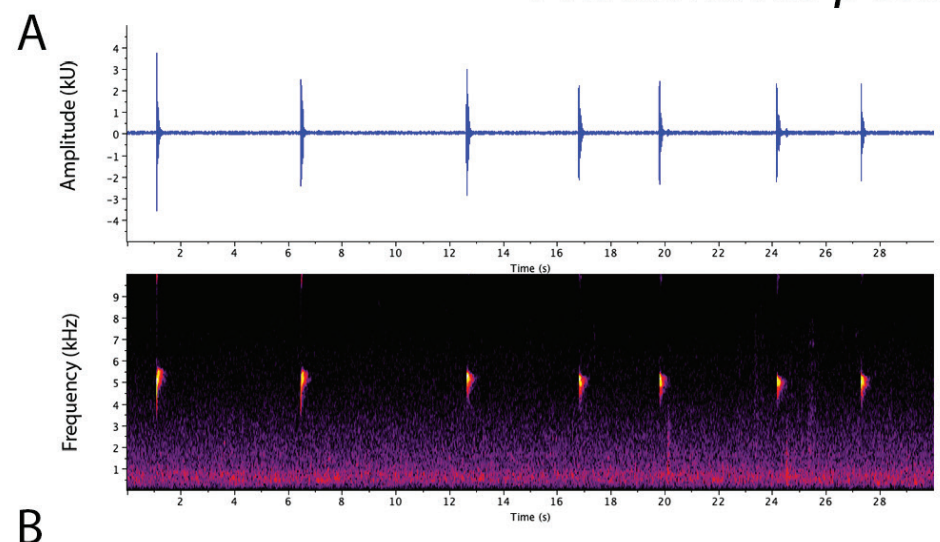

B
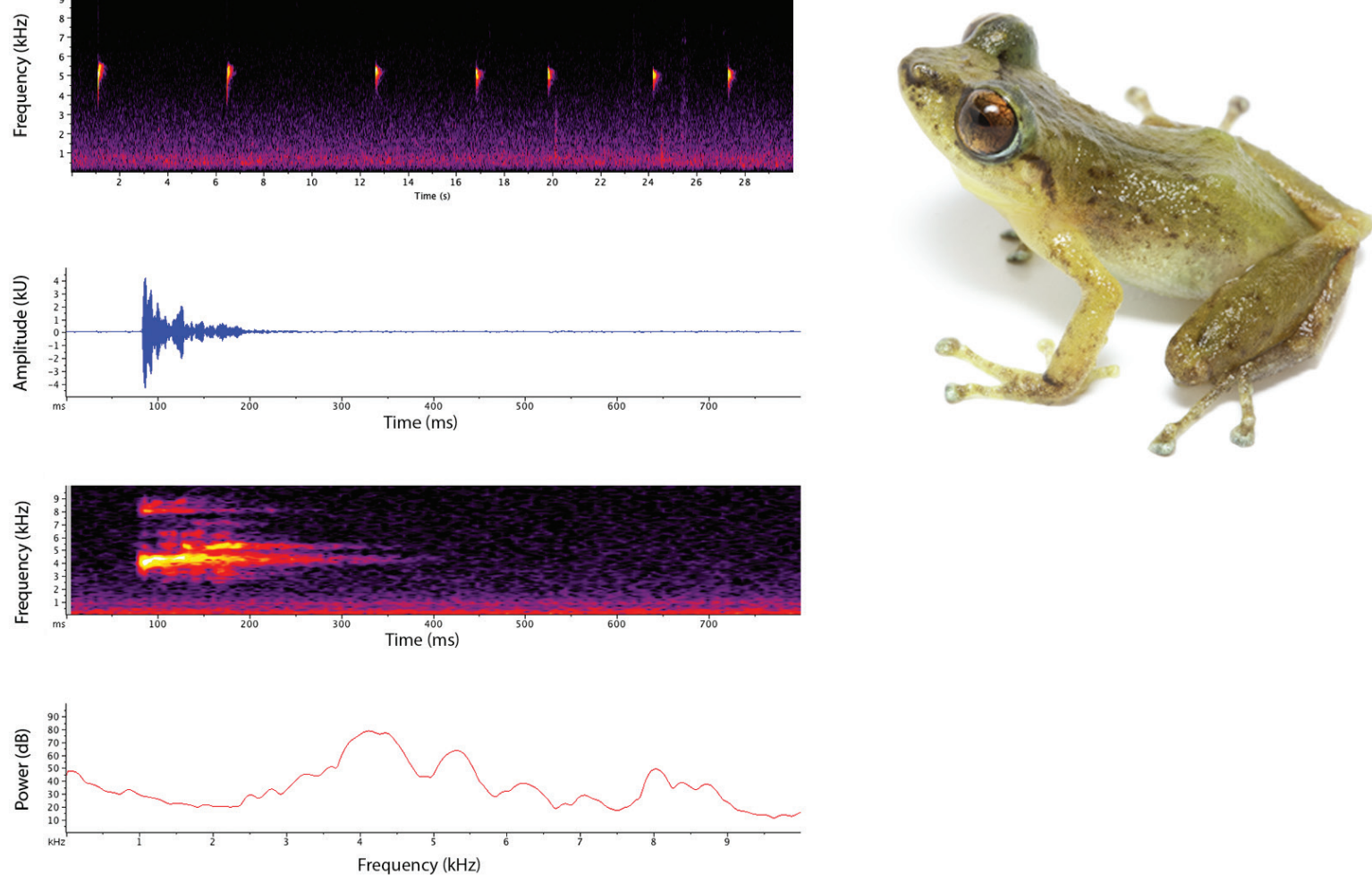

C

\section{Pristimantis petersi}
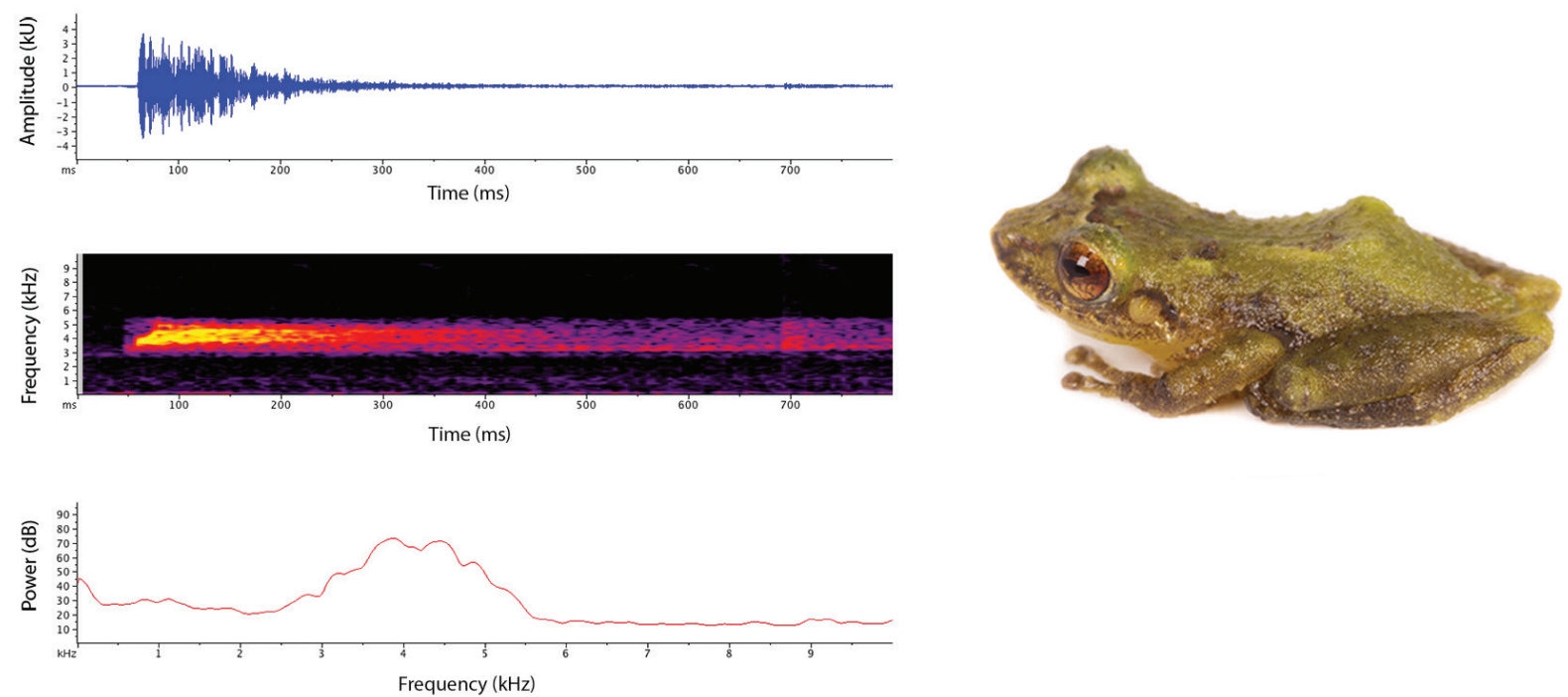

Figure 8. Advertisement calls of Pristimantis petersioides sp. nov. and Pristimantis petersi. (A) oscillogram and spectrogram of a call series of Pristimantis petersioides sp. nov., (B) oscillogram (top), spectrogram (middle), and power spectrum (bottom) of a single call of Pristimantis petersioides sp. nov. and (C) oscillogram (top), spectrogram (middle), and power spectrum (bottom) of a single call of Pristimantis petersi. 
similarity between the new species and its sister species, Pristimantis petersi.

Conservation status. Four out of six known localities are inside National Parks (Sardinayacu in Parque Nacional Sangay and Ankaku, Zarentza and Salcedo-Tena road in Parque Nacional Llanganates); nonetheless, based on a vegetation cover map (Ministerio del Ambiente 2018a) and a deforestation map 2016-2018 (Ministerio del Ambiente 2018b), Zarentza is $<1 \mathrm{~km}$ from deforested areas for agriculture. At the year of collection (2009) the locality at Salcedo-Tena highway was in a forested region with small, deforested patches at distances $>2.5 \mathrm{~km}$ (based on a 2008 deforestation map by Ministerio de Ambiente). Sardinaya$\mathrm{cu}$, refuge 3 occur $>6 \mathrm{~km}$ from pastures, while Sardinayacu, refuge 1 is $<0.5 \mathrm{~km}$ from deforested areas for agriculture.

In Sardinayacu, this species was one of the most common during surveys (24 individuals found in 9 days by 13 people) which suggest it can be locally abundant. Brito et al. (2017) also reported abundant populations in the upper basin of the Upano river, Sangay National Park, Morona Santiago Province (referred both as "Pristimantis peter$s i$ " and also " $P$. aff. petersi"). Its extent of occurrence is

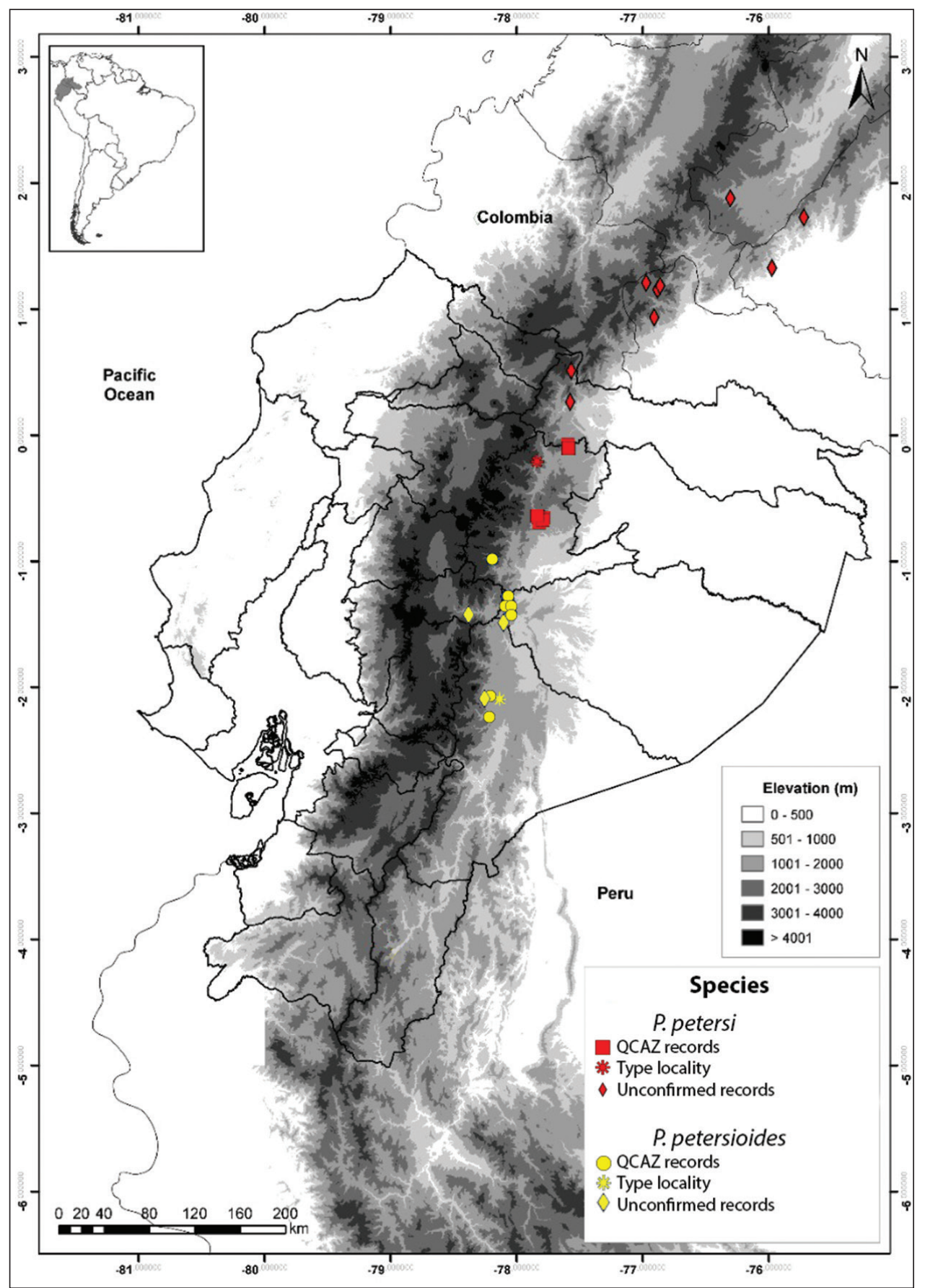

Figure 9. Records of Pristimantis petersioides sp. nov. (yellow) and P. petersi (red). Confirmed records are based on specimens deposited at the Museum of Zoology, Pontificia Universidad Católica del Ecuador. Unconfirmed records (diamonds) from Brito et al. (2017), Lynch and Duellman (1980), Mueses-Cisneros (2005), and Stuart et al. (2008). 
$1402 \mathrm{~km}^{2}$ (based on a minimum convex polygon). Despite being locally abundant, we consider Pristimantis petersioides sp. nov. to be in the Red List category Vulnerable (VU) following B1, B2ab(iii) IUCN criteria because: (i) it is only known from six localities (sensu IUCN 2017), (ii) its Extent of Ocurrence is less than $5000 \mathrm{~km}^{2}\left(1433 \mathrm{~km}^{2}\right)$; and approximately $9 \%$ of its Extent of Ocurrence has been affected by deforestation, human settlements and agriculture (Fig. 10).

Remarks. Pristimantis petersioides sp. nov. differs from $P$. sp. (QCAZ 60398, from Bombuscaro) by the snout shape (in dorsal view, rounded in $P$. petersioides sp. nov., subacuminate in $P$. sp. QCAZ60398), venter texture (weakly areolate in $P$. petersioides sp. nov.; coarsely areolate in $P$. sp. QCAZ60398), presence of small rostral papilla (absent in $P$. sp. QCAZ60398); furthermore, $P$. petersioides sp. nov. bears a complete, rounded tympanic annulus, weakly obscured posterodorsally by a thin supratympanic fold (tympanic annulus concealed posterodorsally by a thick supratympanic fold in $P$. sp. QCAZ60398). It differs from $P$. nankints by snout shape in dorsal view (rounded to truncate in $P$. petersioides sp. nov. vs. acuminate in $P$. nankints).

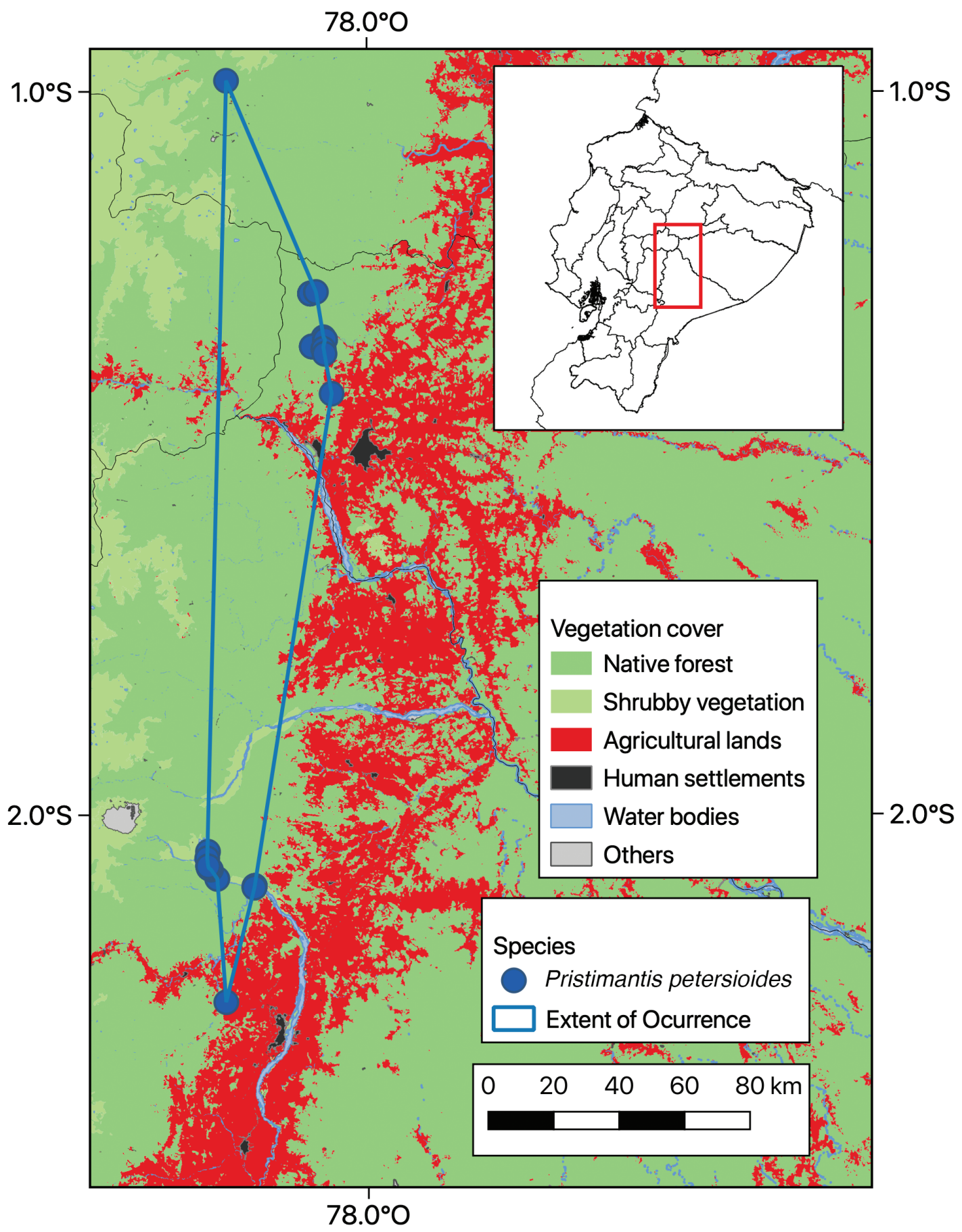

Figure 10. Records of Pristimantis petersioides sp. nov. (blue circles) and its Extent of Ocurrence. Colors indicate vegetation cover based on Ministerio de Ambiente (2018a). 


\section{Discussion}

\section{On the identity of Pristimantis petersi}

Pristimantis petersi was considered to have a wide distribution from the central Andes of Colombia in Caquetá, Huila, and Putumayo (Lynch and Duellman 1980; Mueses-Cisneros 2005; Stuart et al. 2008), to the eastern slopes of the Ecuadorian Andes, from Sucumbíos to Morona Santiago Provinces (Brito et al. 2017; Ron et al. 2019). Herein, we show that it was composed of two species which appear to be allopatric, south and north of the Quilindaña paramos in Napo Province.

Lynch and Duellman (1980) remark of size differences between populations from the north and south of "P. petersi" was not supported in our data but their suspicion of the distinctiveness of the populations from the Pastaza trench was correct. Based in our review, we tentatively consider Pristimantis petersi as distributed from the central Andes of Colombia to Napo Province (Fig. 9). We recommend verifying the identity of Colombian populations using genetic data. Recent reviews of Andean Pristimantis indicate that species usually have a restricted distribution (e.g., Páez and Ron 2019). The geographic distance of Colombian populations (up to $320 \mathrm{~km}$ from the type locality) suggest that, at least some of them, could represent a separate species.

Guayasamin and Funk (2009) reported an abundant population of "Pristimantis cf. petersi" at Yanayacu Biological Station. Examination of voucher specimens deposited at the QCAZcollection indicate that they are not conspecific with $P$. petersi nor $P$. petersioides sp. nov.

Our results and those of previous systematic reviews (show that eastern montane forests still harbor many undescribed species of Pristimantis. Similar findings have been previously reported by Ortega et al. (2015), Páez and Ron (2019), and Ron et al. (2020). As in previous reviews (e.g., Restrepo et al. 2017; Páez and Ron 2019), we also found broad intraspecific and intrapopulation variation in dorsal color within $P$. petersioides sp. nov. (Figs 6, 7) and $P$. petersi (Fig. 11). This large intraspecific and intrapopulation variation hinders the use of dorsal coloration for diagnosis between both species. Most individuals have greenish dorsal color which is characteristic of several species of the P. lacrimosus group. We did not find diagnostic morphological characters to distinguish the new species from Pristimantis petersi, which highlights the importance of including molecular and bioacoustic data to clarify species identity.

\section{Use of bioacoustics for species delimitation}

Similar to Páez and Ron (2019), our morphometric analysis was of little help to distinguish closely related species of Pristimantis. In contrast, advertisement calls and genetic data indicate that $P$. petersioides $\mathrm{sp}$. nov. represents a lineage independent from $P$. petersi. We found differences with little or no overlap in two static call traits, call duration and dominant frequency (Köhler et al. 2017). Moreover, differences in call frequency are likely an underestimate because the calling males of $P$. petersioides sp. nov. were larger than those from the recorded chorus of $P$. petersi. Because there is an inverse relationship between body size and call frequency (Gerhardt and Huber 2002), the higher frequency of the call of $P$. petersioides sp. nov. would be likely higher after a size correction.

Bioacoustic comparisons are of importance for taxonomy because advertisement calls mediate species recognition and mate choice (e.g., Ryan and Rand 1995). It has been widely accepted that calls are among the most useful characters differentiating closely related anuran species (Vences and Wake 2007). However, calls have been of limited use in the taxonomy of Pristimantis (Duellman and Lehr 2009). Our study and some recent works (Hutter and Guayasamin 2015; Páez and Ron 2019; Székely et al. 2020) highlight the usefulness of bioacoustic characters in Pristimantis taxonomy. Future taxonomic reviews will benefit from a more comprehensive knowledge of advertisement calls in Pristimantis.

\section{Acknowledgements}

Laboratory and fieldwork was funded by a grant from SENESCYT (Arca de Noé Initiative; S. R. Ron and O. Torres-Carvajal principal investigators) and grants from Dirección General Académica of Pontificia Universidad Católica del Ecuador. We are thankful to the QCAZ molecular laboratory, specially to Ana Belén Carrillo and Claudia Terán for their guidance during labwork. The staff of the QCAZ herpetology collection, Fernando Ayala, Santiago Guamán, and Diego Paucar helped with preservation and processing of the specimens. Diego Batallas provided a call recording from Sangay National Park. Daniel Rivadeneira made call recordings. Special thanks to Jhael Ortega and Yerka Sagredo for their assistance with specimen examination. Marcel Caminer, María José Navarrete, and Jhael Ortega provided helpful observations and guidance during this research and constructive comments to previous versions of this manuscript. Alex Achig, Silvia Aldás, Ángel Alvarado, Fernando Alvarado, Verónica Andrade, Pamela Baldeón, Marcel Caminer, Andrea Correa, Santiago Guamán, María José Navarrete, Darwin Nuñez, Fernando Nuñez, Kunam Nucirquia, Diego Paucar, Javier Pinto, Belén Proaño, Daniel Rivadeneira, Juan Carlos Sánchez, Elicio Tapia, David Velalcázar, Pablo Venegas, and Mario Yánez collected specimens. Pablo Venegas provided a tissue from Peru. We thank Jorge Brito for sharing photographs. The ecuadorian Ministerio del Ambiente provided research permits numbers 008-09 IC-FAU-DNB/MA, 001-11 IC-FAU-DNB/MA, 002-16 IC-FAU-DNB/MA and MAE-DNB-ARRGG-CM-2014-0002. 
A

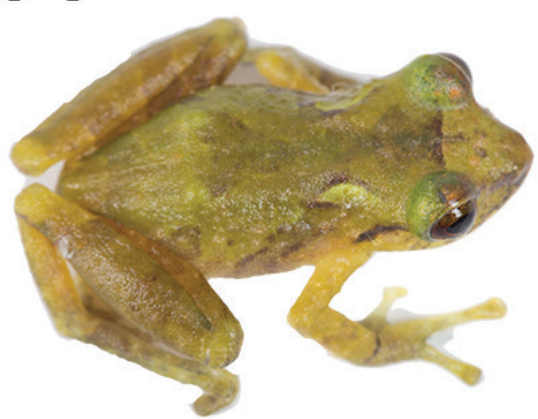

B
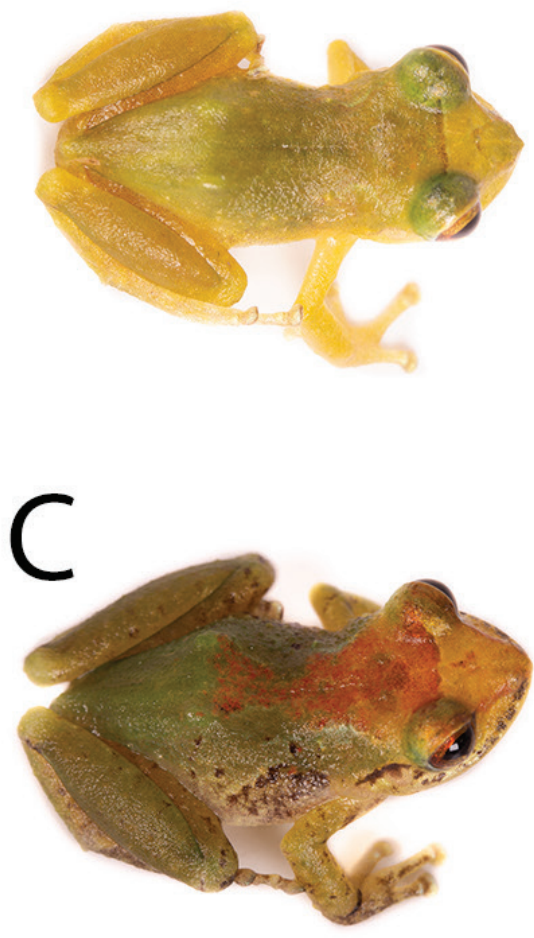

D

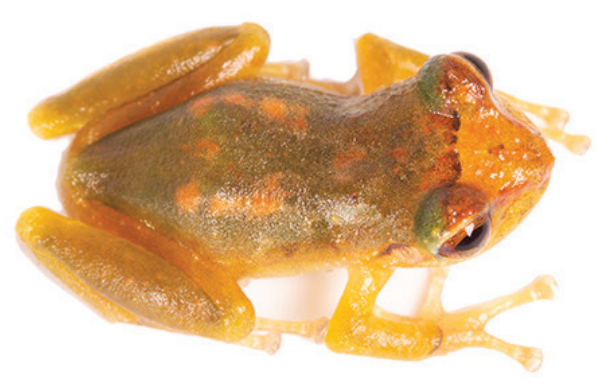

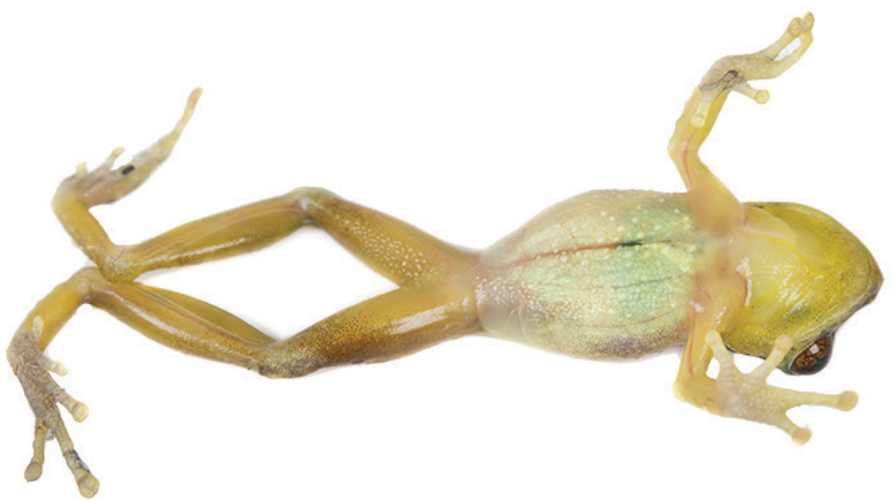
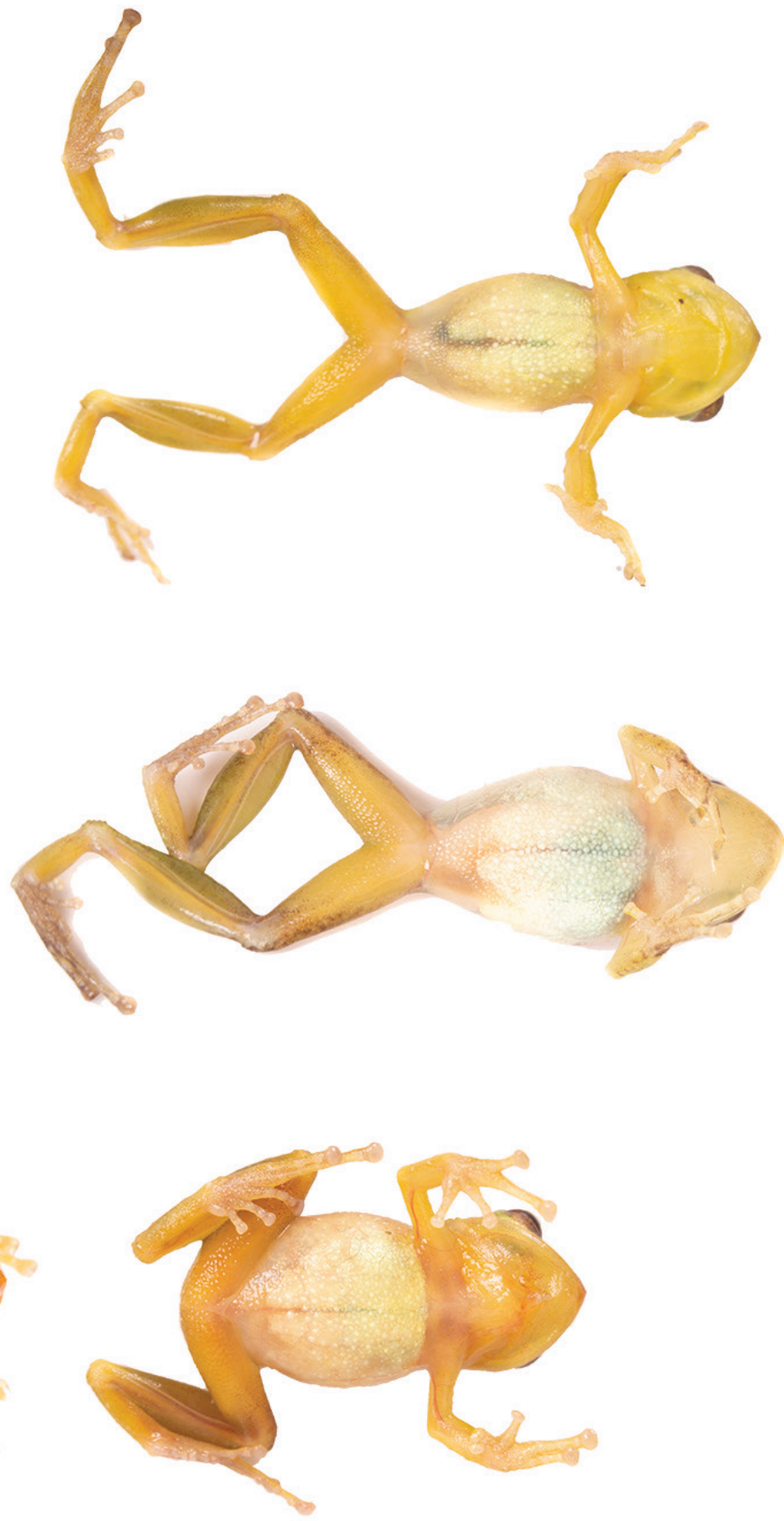

Figure 11. Variation in live adult individuals of Pristimantis petersi. A QCAZ63452 (SVL $17.42 \mathrm{~mm}$ ), B QCAZ63453 (SVL 17.75 mm), C QCAZ63454 (SVL 21.11 mm), D QCAZ63456 (SVL 19.11 mm). Photographs by Santiago R. Ron A, by David Velalcázar B-D. 


\section{References}

Andersson LG (1945) Batrachians from East Ecuador collected 1937, 1938 by Wm. Clarke-MacIntyre and Rolf Blomberg. Arkiv för Zoologi. Kongliga Svenska Vetenskaps-Akademiens, Stockholm. Arnoldia, Zimbabwe 37: e32143.

AmphibiaWeb (2019) AmphibiaWeb: information on amphibian biology and conservation. University of California Berkeley. http:// amphibiaweb.org/

Arteaga-Navarro AF, Bustamante L, Guayasamin JM (2013) The amphibians and reptiles of Mindo. Universidad Tecnológica Indoamericana, Quito, Ecuador, 258 pp.

Batallas D, Brito J (2014) Nueva especie de rana del género Pristimantis del grupo lacrimosus (Amphibia: Craugastoridae) del Parque Nacional Sangay, Ecuador. Papéis Avulsos de Zoologia. São Paulo 54: 51-62. https://doi.org/10.1590/0031-1049.2014.54.05

Batallas DR, Brito JM (2016) Análisis bioacústico de las vocalizaciones de seis especies de anuros de la laguna Cormorán, complejo lacustre de Sardinayacu, Parque Nacional Sangay, Ecuador. Revista Mexicana de Biodiversidad 87: 1292-1300. https://doi.org/10.1016/j. rmb.2016.10.005

Boettger O (1892) Katalog der Batrachier-Sammlung im Museum der Senckenbergischen Naturforschenden Gesellshaft in Frankfurt am Main. Gebrüder Knauer, Frankfurt am Main.

Boulenger GA (1880) Reptiles et batraciens recueillis par M. Émile de Ville dan les Andes de l'Équateur. Bulletin de la Société Zoologique de France 5: 41-48.

Boulenger GA (1899) Descriptions of new reptiles and batrachians collected by Mr. P. O. Simons in the Andes of Ecuador. Annals and Magazine of Natural History, Series 7: 454-457. https://doi. org/10.1080/00222939908678229

Boulenger GA (1902) Descriptions of new batrachians and reptiles from north western Ecuador. Annals and Magazine of Natural History, Series 7(9): 51-57. https://doi.org/10.1080/00222930208678538

Brito JM, Batallas D, Yánez-Muñoz MH (2017) Ranas terrestres Pristimantis (Anura: Craugastoridae) de los bosques montanos del río Upano, Ecuador: Lista anotada, patrones de diversidad y descripción de cuatro especies nuevas . Neotropical Biodiversity 3: 125-156. https://doi.org/10.1080/23766808.2017.1299529

Charif RA, Waack AM, Strickman LM (2010) Raven Pro 1.4 User's Manual. Cornell Lab of Ornithology, Ithaca.

Chávez G, Catenazzi A (2016) A new species of frog of the genus Pristimantis from Tingo María National Park, Huánuco Department, central Peru (Anura, Craugastoridae). ZooKeys 610: 113-130. https:// doi.org/10.3897/zookeys.610.8507

Chernomor O, von Haeseler A, Minh BQ (2016) Terrace aware data structure for phylogenomic inference from supermatrices. Systematic Biology 65: 997-1008. https://doi.org/10.1093/sysbio/syw037

Despax R (1911) Mission géodésique de l'Équateur. Collections recueilles par M. le Dr. Rivet. Batraciens anoures. Bulletin du Museum National d'Histoire Naturelle. Paris 17: 90-94.

Duellman WE (1978) Three new species of Eleutherodactylus from Amazonian Perú (Amphibia: Anura: Leptodactylidae). Herpetologica 34: 264-270.

Duellman WE (1990) A new species of Eleutherodactylus from the Andes of northern Peru (Anura: Leptodactylidae). Journal of Herpetology 24: 348-350. https://doi.org/10.2307/1565048
Duellman WE, Pramuk JB (1999) Frogs of the genus Eleutherodactylus (Anura: Leptodactylidae) in the Andes of northern Peru. Scientific Papers. Natural History Museum, University of Kansas 13: 1-78. https://doi.org/10.5962/bhl.title.16169

Duellman WE, Lehr E (2009) Terrestrial-breeding Frogs (Strabomantidae) in Peru. Nature und Tier Verlag, Munster, 382 pp.

Edgar RC (2004) MUSCLE: multiple sequence alignment with high accuracy and high throughput. Nucleic Acids Research 32: 17921797. https://doi.org/10.1093/nar/gkh340

Feller AE, Hedges SB (1998) Molecular Evidence for the Early History of Living Amphibians. Molecular Phylogenetics and Evolution 9: 509-516. https://doi.org/10.1006/mpev.1998.0500

Flores G (1988) Two new species of Ecuadorian Eleutherodactylus (Leptodactylidae) of the E. crucifer assembly. Journal of Herpetology 22: 34-41. https://doi.org/10.2307/1564354

Frost DR (2009) Amphibian Species of the World: An Online Reference. Version 5.3. (12 February 2009). Electronic Database. American Museum of Natural History, New York.

Frost DR (2021) Amphibian Species of the World: an Online Reference [Internet]. Version 6.1. New York (NY): American Museum of Natural History. http://research.amnh.org/herpetology/amphibia/index. html [accessed March 12 2021]

Gerhardt HC, Huber F (2002) Acoustic communication in insects and anurans. The University of Chicago Press, Chicago.

Goebel AM, Donnelly MA, Atz M (1999) PCR primers and amplification methods for $12 \mathrm{~S}$ ribosomal DNA, the control region, cytochrome oxidase I, and cytochrome b in bufonids and other frogs, and an overview of PCR rimers which have amplified DNA in amphibians successfully. Molecular Phylogenetics and Evolution 11: 163-199. https://doi.org/10.1006/mpev.1998.0538

González-Durán GA, Targino M, Rada M, Grant T (2017) Phylogenetic relationships and morphology of the Pristimantis leptolophus species group (Amphibia: Anura: Brachycephaloidea), with the recognition of a new species group in Pristimantis Jiménez de la Espada, 1870. Zootaxa 4243: 42-74. https://doi.org/10.11646/zootaxa.4243.1.2

Guayasamin JM, Ron SR, Cisneros-Heredia DF, Lamar WW, McCracken SF (2006) A new species of frog of the Eleutherodactylus lacrimosus assemblage (Leptodactylidae) from the western Amazon Basin, with comments on the utility of canopy surveys in lowland rainforest. Herpetologica 62: 191-202. https://doi.org/10.1655/05-40.1

Guayasamin JM, Funk WC (2009) The amphibian community at Yanayacu Biological Station, Ecuador, with a comparison of vertical microhabitat use among Pristimantis species and the description of a new species of the Pristimantis myersi group. Zootaxa 2220: 41-66. https://doi.org/10.11646/zootaxa.2220.1.2

Guayasamin JM, Hutter CR, Tapia EE, Culebras J, Peñafiel N, Pyron RA, Morochz CW, Funk C, Arteaga A (2017) Diversification of the rainfrog Pristimantis ornatissimus in the lowlands and Andean foothills of Ecuador. PLoS ONE 12: e0172615. https://doi.org/10.1371/ journal.pone.0172615

Guindon S, Dufayard JF, Lefort V, Anisimova M, Hordijk W, Gascuel O (2010) New algorithms and methods to estimate maximum-likelihood phylogenies: assessing the performance of PhyML 3.0. Systematic Biology 59: 307-321. https://doi.org/10.1093/sysbio/syq010

Hedges SB, Duellman WE, Heinicke MP (2008) New World direct-developing frogs (Anura: Terrarana): Molecular phylogeny, classifica- 
tion, biogeography, and conservation. Zootaxa 1737: 1-182. https:// doi.org/10.11646/zootaxa.1737.1.1

Heinicke MP, Duellman WE, Hedges SB (2007) Major Caribbean and Central American frog faunas originated by ancient oceanic dispersal. Proceedings of the National Academy of Sciences of the United States of America 104: 10092-10097. https://doi.org/10.1073/ pnas.0611051104

Heyer WR, Hardy LM (1991) A new species of frog of the Eleutherodactylus lacrimosus assembly from Amazonia, South America (Amphibia: Anura: Leptodactylidae). Proceedings of the Biological Society of Washington 104: 436-447.

Hutter CR, Guayasamin JM (2015) Cryptic diversity concealed in the Andean cloud forests: two new species of rainfrogs (Pristimantis) uncovered by molecular and bioacoustic data. Neotropical Biodiversity 1: 36-59. https://doi.org/10.1080/23766808.2015.1100376

IUCN Standards and Petitions Subcommittee (2017) Guidelines for Using the IUCN Red List Categories and Criteria. Version 13. Prepared by the Standards and Petitions Subcommittee. http://www.iucnredlist.org/documents/RedListGuidelines.pdf [Accessed june 2019]

Jiménez de la Espada M (1870) Fauna neotropicalis species quaedam nondum cognitae. Jornal de Sciências, Mathemáticas, Physicas e Naturaes. Lisboa 3: 57-65.

Jiménez de la Espada M (1875) Vertebrados del Viaje al Pacífico Verificado de 1862 a 1865 por una Comisión de Naturalistas Enviada por el Gobierno Español. Batracios. Madrid: A. Miguel Ginesta. https:// doi.org/10.5962/bhl.title.5769

Kalyaanamoorthy S, Minh BQ, Wong TK, von Haeseler A, Jermiin LS (2017) ModelFinder: Fast model selection for accurate phylogenetic estimates. Nature Methods 14: 587-589. https://doi.org/10.1038/ nmeth. 4285

Köhler J, Morales VR, Lotters S, Reichle S, Aparicio J (1998)A new green species of frog, genus Eleutherodactylus, from Bolivia and Peru (Amphibia, Anura, Leptodactylidae). Studies on Neotropical Fauna and Environment 33:93-99. https://doi.org/10.1076/ snfe.33.2.93.2158

Köhler J, Jansen M, Rodríguez A, Kok PJR, Toledo LF, Emmrich M, Glaw F Haddad CFB, Rödel M-O, Vences M (2017) The use of bioacoustics in anuran taxonomy: theory, terminology, methods and recommendations for best practice. Zootaxa 4251: 001-124. https:// doi.org/10.11646/zootaxa.4251.1.1

Kumar S, Stecher G, Tamura K (2016) MEGA7: Molecular Evolutionary Genetics Analysis version 7.0 for bigger datasets. Molecular Biology and Evolution 33: 1870-1874. https://doi.org/10.1093/molbev/msw054

Lehr E, Lundberg M, Aguilar C, von May R (2006) New species of Eleutherodactylus (Anura: Leptodactylidae) from the eastern Andes of central Peru with comments on central Peruvian Eleutherodactylus. Herpetological Monographs 20: 105-128. https://doi. org/10.1655/0733-1347(2007)20[105:NSOEAL]2.0.CO;2

Lehr E, Torres-Gastello CP, Suárez-Segovia J (2007) A new species of arboreal Eleutherodactylus (Anura: Leptodactylidae) from the Amazonian lowlands of central Peru. Herpetologica 63: 94-99. https:// doi.org/10.1655/0018-0831(2007)63[94:ANSOAE]2.0.CO;2

Lehr E, Gregory C, Catenazzi A (2013) A new species of Pristimantis (Amphibia: Anura: Strabomantidae) from the Río Abiseo National Park, Peru. Zootaxa 3731: 201-211. https://doi.org/10.11646/zootaxa.3731.2.1
Lynch JD (1973) A new narrow-toed frog from Andean Ecuador (Leptodactylidae: Eleutherodactylus). Copeia 1973: 222-225. https://doi. org/10.2307/1442960

Lynch JD (1974) New species of frogs (Leptodactylidae: Eleutherodactylus) from the Amazonian lowlands of Ecuador. Occasional Papers of the Museum of Natural History, University of Kansas 31: 1-22. https://doi.org/10.5962/bhl.part.29037

Lynch JD (1976) New species of frogs (Leptodactylidae: Eleutherodactylus) from the Pacific versant of Ecuador. Occasional Papers of the Museum of Natural History, University of Kansas 55: 1-33. https:// doi.org/10.5962/bhl.part.29037

Lynch JD (1979) Leptodactylid frogs of the genus Eleutherodactylus from the Andes of southern Ecuador. Miscellaneous Publication, Museum of Natural History, University of Kansas 66: 1-62. https:// doi.org/10.5962/bhl.title. 16268

Lynch JD, Duellman WE (1980) The Eleutherodactylus of the Amazonian slopes of the Ecuadorian Andes (Anura: Leptodactylidae). Miscelaneous Publication, Museum of Natural History, University of Kansas 69: 1-86. https://doi.org/10.5962/bhl.title.16222

Lynch JD (1980) Eleutherodactylus eremitus, a new trans-Andean species of the lacrimosus assembly from Ecuador (Amphibia: Leptodactylidae). Breviora. Museum of Comparative Zoology, Cambridge, Massachusetts 462: 1-7. https://doi.org/10.2307/1444513

Lynch JD, Ruiz-Carranza PM (1985) A synopsis of the frogs of the genus Eleutherodactylus from the Sierra Nevada de Santa Marta. Occasional Papers of the Museum of Zoology, University of Michigan 711: 1-59.

Lynch JD (1991) Three replacement names for preoccupied names in the genus Eleutherodactylus (Amphibia: Leptodactylidae). Copeia 1991: 1138-1139. https://doi.org/10.2307/1446116

Lynch JD (1996) Replacement names for three homonyms in the genus Eleutherodactylus (Anura: Leptodactylidae). Journal of Herpetology 30: 278-280. https://doi.org/10.2307/1565525

Lynch JD, Duellman WE (1997) Frogs of the genus Eleutherodactylus in western Ecuador: systematics, ecology, and biogeography. Special Publications, Natural History Museum University of Kansas 23: 1-236. https://doi.org/10.5962/bhl.title.7951

Maddison WP, Maddison DR (2018) Mesquite: a modular system for evolutionary analysis. Version 3.51. http://www.mesquiteproject.org [accessed 05 may 2019]

McCracken SF, Forstner MR, Dixon JR (2007) A new species of the Eleutherodactylus lacrimosus assemblage (Anura, Brachycephalidae) from the lowland rainforest canopy of Yasuni National Park, Amazonian Ecuador. Phyllomedusa. Belo Horizonte 6: 23-36. https://doi.org/10.11606/issn.2316-9079.v6i1p23-35

Mendoza AM, Ospina OE, Cárdenas-Henao H, García-R JC (2015) A likelihood inference ofhistorical biogeography in the world's most diverse terrestrial vertebrate genus: Diversification of direct-developing frogs (Craugastoridae: Pristimantis) across the Neotropics. Molecular Phylogenetic Evolution 85: 50-58. https:/doi. org/10.1016/j.ympev.2015.02.001

Ministerio del Ambiente (2018a) Cobertura de la tierra, Ecuador. Map. http://ide.ambiente.gob.ec/mapainteractivo/ [15 April 2020]

Ministerio del Ambiente (2018b) Deforestación periodo 2016-2018. Map. http://ide.ambiente.gob.ec/mapainteractivo/ [15 April 2020]

Moen DS, Wiens JJ (2009) Phylogenetic evidence for competitively driven divergence: body-size evolution in Caribbean treefrogs ( $\mathrm{Hyl}$ - 
idae: Osteopilus). Evolution 63: 195-214. https://doi.org/10.1111/ j.1558-5646.2008.00538.x

Morales VR (2007) Una especie nueva de Eleutherodactylus (Amphibia: Anura: Brachycephalidae) de la Amazonía central del Perú. Biotempo. Lima 7: 5-11. https://doi.org/10.31381/biotempo.v7i0.868

Moravec J, Lehr E, Pérez-Peña PE, Lopez JJ, Gagliardi-Urrutia LAG, Arista-Tuanama I (2010) A new green, arboreal species of Pristimantis (Anura: Strabomantidae) from Amazonian Peru. Vertebrate Zoology. Museum für Tierkunde, Dresden 60: 225-232.

Moravec J, Lehr E, Kodejš K (2020) A new species of Pristimantis (Amphibia, Anura, Strabomantidae) from the Pui Pui Protected Forest (central Peru), with comments on Pristimantis albertus Duellman \& Hedges, 2007. ZooKeys 994: 125-148. https://doi.org/10.3897/ zookeys.994.56277

Mueses-Cisneros JJ (2005) Fauna anfibia del Valle de Sibundoy, Putumayo-Colombia. Caldasia. Bogotá 27: 229-242.

Nguyen LT, Schmidt HA, von Haeseler A, Minh BQ (2015) IQ-TREE: A fast and effective stochastic algorithm for estimating maximum likelihood phylogenies. Molecular Biology and Evolution 32: 268 274. https://doi.org/10.1093/molbev/msu300

Ortega-Andrade HM, Rojas-Soto OR, Valencia JH, de los Monteros AE, Morrone JJ, Ron SR, Cannatella DC (2015) Insights from integrative systematics reveal cryptic diversity in Pristimantis frogs (Anura: Craugastoridae) from the Upper Amazon Basin. PLoS ONE 10: e0143392. https://doi.org/10.1371/journal.pone.0143392

Ospina-Sarria JJ, Duellman WE (2019) Two new species of Pristimantis (Amphibia: Anura: Strabomantidae) from southwestern Colombia. Herpetologica 75: 85-95. https://doi. org/10.1655/D-18-00019

Padial JM, Grant T, Frost DR (2014) Molecular systematics of terraranas (Anura: Brachycephaloidea) with an assessment of the effects of alignment and optimality criteria. Zootaxa 3825: 001-132. https:// doi.org/10.11646/zootaxa.3825.1.1

Páez NB, Ron SR (2019) Systematics of Huicundomantis, a new subgenus of Pristimantis (Anura, Strabomantidae) with extraordinary cryptic diversity and eleven new species. Zookeys 868: 1-112. https://doi.org/10.3897/zookeys.868.26766

Peters WCH (1863) Über eine neue Schlangen-Gattung, Styporhynchus, und verschiedene andere Amphibien des zoologischen Museum. Monatsberichte der Königlichen Preussische Akademie des Wissenschaften zu Berlin 1863: 399-413.

Peters WCH (1870) Über mexicanische Amphibien, welche Hr. Berkenbusch in Puebla auf Veranlassung des Hrn. Legationsrather von Schlözer dem zoologischen Museum zugesandt hat. Monatsberichte der Königlichen Preussische Akademie des Wissenschaften zu Berlin 1869: 874-881.

Restrepo A, Velasco JA, Daza JM (2017) Extinction risk or lack of sampling in a threatened species: genetic structure and environmental suitability of the neotropical frog Pristimantis penelopus (Anura: Craugastoridae). Papéis Avulsos de Zoologia 57: 1-15. https://doi org/10.11606/0031-1049.2017.57.01

Reyes-Puig C, Reyes-Puig JP, Velarde-Garcez DA, Davalos N, Mancero E, Navarrete MJ, Yanez-Munoz MH, Cisneros-Heredia DF, Ron SR (2019) A new species of terrestrial frog Pristimantis (Strabomanti- dae) from the upper basin of the Pastaza River, Ecuador. Zookeys 832: 113-133. https://doi.org/10.3897/zookeys.832.30874

Rivera-Correa M, Daza JM (2016) Molecular phylogenetics of the Pristimantis lacrimosus species group (Anura: Craugastoridae) with the description of a new species from Colombia. Acta Herpetologica 11: 31-45.

Rivera-Correa M, Daza-R JM (2020) Out of the blue: A new rain frog species of the genus Pristimantis (Anura: Craugastoridae) from the northern Cordillera Central in Colombia. Zootaxa 4838: 83-101. https://doi.org/10.11646/zootaxa.4838.1.4

Ron SR, Merino-Viteri A, Ortiz DA (2019) Anfibios del Ecuador. Version 2019.0. Museo de Zoología, Pontificia Universidad Católica del Ecuador. https://bioweb.bio/faunaweb/amphibiaweb [5 May 2019]

Ron SR, Carrion J, Caminer MA, Sagredo Y, Navarrete MJ, Ortega JA, Varela-Jaramillo A, Maldonado-Castro GA, Terán C (2020) Three new species of frogs of the genus Pristimantis (Anura: Strabomantidae) with a redefinition of the P. lacrimosus species group. ZooKeys 993: 121-155. https://doi.org/10.3897/zookeys.993.53559

Ryan MJ, Rand AS (1995) Female responses to ancestral advertisement calls in Tungara frogs. Science 269: 390-392. https://doi. org/10.1126/science. 269.5222 .390

Savage JM (1965) A new bromeliad frog of the genus Eleutherodactylus from Costa Rica. Bulletin of the Southern California Academy of Sciences 64: 106-110.

Shepack A, von May R, Ttito A, Catenazzi A (2016) A new species of Pristimantis (Amphibia, Anura, Craugastoridae) from the foothills of the Andes in Manu National Park, southeastern Peru. ZooKeys 594: 143-164. https://doi.org/10.3897/zookeys.594.8295

Shreve B (1935) On a new teiid and Amphibia from Panama, Ecuador, and Paraguay. Occasional Papers of the Boston Society of Natural History 8: 209-218.

Stuart SN, Hoffmann M, Chanson J, Cox N, Berridge R, Ramani P, Young B (2008) Threatened Amphibians of the World. Barcelona, Spain; International Union for the Conservation of Nature, Gland. Switzerland; Conservation International, Arlington, Virginia, U.S.A.: Lynx Editions.

Székely P, Eguiguren JS, Ordóñez-Delgado L, Armijos-Ojeda D, Székely D (2020) Fifty years after: A taxonomic revision of the amphibian species from the Ecuadorian biodiversity hotspot Abra de Zamora, with description of two new Pristimantis species. PLoS ONE 15(9): e0238306. https://doi.org/10.1371/journal.pone.0238306

Urgiles VL, Székely P, Székely D, Christodoulides N, Sanchez-Nivicela JC, Savage AE (2019) Genetic delimitation of Pristimantis orestes (Lynch, 1979) and P. saturninoi Brito et al., 2017 and description of two new terrestrial frogs from the Pristimantis orestes species group (Anura, Strabomantidae). Zookeys 864: 111-146. https://doi. org/10.3897/zookeys.864.35102

Vences M, Wake DB (2007) Speciation, species boundaries and phylogeography of amphibians. In: Heatwole H, Tyler MJ (Eds) Amphibian Biology. Surrey Beatty \& Sons, Chipping Norton, New South Wales, 2613-2671.

Wiens JJ, Fetzner JW, Parkinson CL, Reeder TW (2005) Hylid frog phylogeny and sampling strategies for speciose clades. Systematic Biology 54: 719-748. https://doi.org/10.1080/10635150500234625 


\section{Supplementary material 1}

\section{Collection data for Museum specimens examined in the morphological comparisons}

Authors: Julio C. Carrión-Olmedo, Santiago R. Ron

Data type: Collection data

Explanation note: All specimens are deposited at the amphibian collection of the Zoological Museum (QCAZ), Pontificia Universidad Católica del Ecuador in Quito, Ecuador.

Copyright notice: This dataset is made available under the Open Database License (http://opendatacommons. org/licenses/odbl/1.0). The Open Database License $(\mathrm{ODbL})$ is a license agreement intended to allow users to freely share, modify, and use this Dataset while maintaining this same freedom for others, provided that the original source and author(s) are credited.

Link: https://doi.org/10.3897/evolsyst.5.62661.suppl1

\section{Supplementary material 2}

\section{Best-fit models of DNA evolution for partitions of the phylogenetic analyses}

Authors: Julio C. Carrión-Olmedo, Santiago R. Ron

Data type: Phylogenetic

Explanation note: Models were chosen according to the BIC criterion.

Copyright notice: This dataset is made available under the Open Database License (http://opendatacommons. org/licenses/odbl/1.0). The Open Database License $(\mathrm{ODbL})$ is a license agreement intended to allow users to freely share, modify, and use this Dataset while maintaining this same freedom for others, provided that the original source and author(s) are credited.

Link: https://doi.org/10.3897/evolsyst.5.62661.suppl2

\section{Supplementary material 3}

\section{Mitochondrial DNA and RAG1 phylogenetic trees}

Authors: Julio C. Carrión-Olmedo, Santiago R. Ron Data type: Phylogenetic

Explanation note: The Pristimantis lacrimosus species group is shown in green.

Copyright notice: This dataset is made available under the Open Database License (http://opendatacommons. org/licenses/odbl/1.0). The Open Database License $(\mathrm{ODbL})$ is a license agreement intended to allow users to freely share, modify, and use this Dataset while maintaining this same freedom for others, provided that the original source and author(s) are credited. Link: https://doi.org/10.3897/evolsyst.5.62661.suppl3 